\title{
Illustrated and Illuminated Manuscripts of the Dalä'il al-khayrāt from Southeast Asia
}

\author{
Farouk Yahya | ORCID: 0000-0002-6641-2804 \\ soAs, University of London, London, UK \\ fyı@soas.ac.uk
}

\begin{abstract}
Illustrated and illuminated manuscripts of the Dalāil al-khayrāt from Southeast Asia are an invaluable resource for our understanding of the painting tradition of this region. The many copies now kept in various institutions attest to its popularity, while the lavish treatment often given to manuscripts indicates the high regard local communities had for this text. The types of images featured are similar to those from other parts of the Islamic world, yet these images, as well as the decorative illumination, also reflect local artistic styles. This paper examines a selection of Southeast Asian manuscripts of the Daläil al-khayrāt dating from the eighteenth and nineteenth centuries, situating them both within the broader context of manuscript production and usage, and the pietistic landscape of the region.
\end{abstract}

\section{Keywords}

Dalāil al-khayrāt - al-Jazuli - Aceh - Borneo - Hadhrami - Java - Sulawesi - Sumatra Malay peninsula - Southeast Asia - Sufism

\section{Introduction $^{1}$}

The Dalāil al-khayrāt ("Guidelines to the blessings") is a prayer book containing a collection of blessings upon the Prophet Muhammad. Composed during the fifteenth century by the Moroccan Sufi Abū 'Abdullāh Muhammad ibn

1 Submitted in an earlier version on 1 June 2020. Accepted for publication on 13 October 2020. 
Sulaymān al-Jazūlī al-Simlālī (d. c. 870/1465), ${ }^{2}$ it became immensely successful and was circulated widely across the Sunni Islamic world. Manuscript copies and printed editions of this text were often illustrated. The images they featured include the tombs of the Prophet Muhammad and his two successors (rawda), the Prophet's pulpit (minbar), or scenes of Mecca and Medina. As such, these manuscripts and printed books are an invaluable resource for the study of devotional art in Islam and the transmission of images within the Islamic world. ${ }^{3}$

This article focusses on a selection of illuminated and illustrated manuscripts of the Daläil from Southeast Asia dating from the eighteenth and nineteenth centuries. There are a number of reasons why these manuscripts are important. Firstly, they attest to links and contacts between the region and the broader Islamic world, and the numerous copies that have been produced demonstrate the popularity of the text among local communities. Secondly, they are particularly important for the study of Southeast Asian art. As copies of the Daläil were often illustrated, they assist our understanding of the connections between art and religious practices, and how iconographies that were transmitted into the region were "localized".

2 For a background on al-Jazūlī and his works, see Mohammed Ben Cheneb, "al-Djazūlī," in Encyclopaedia of Islam, New Edition, vol. 2, ed. P. Bearman et al. (Leiden: Brill, 1965), 527-528; Vincent J. Cornell, Realm of the Saint: Power and Authority in Moroccan Sufism (Austin, TX: University of Texas Press, 1998), 167-195.

3 On the Daläil and its illustrations, see Jan Just Witkam, Vroomheid en Activisme in een Islamitisch Gebedenboek (Leiden: Legatum Warnerium, Universiteitsbibliotheek Leiden, 2002); Idem, "The Battle of the Images: Mekka vs. Medina in the Iconography of the Manuscripts of al-Jazūlī's Dalä'il al-Khayrat," in Theoretical Approaches to the Transmission and Edition of Oriental Manuscripts, ed. Judith Pfeiffer and Manfred Kropp (Beirut: Ergon Verlag Würzburg, 2007), 67-82 (text), 295-299 (illustrations); Nurul Iman Rusli et al., Daläil al-Khayrat: Prayer Manuscripts from the 16th-19th Centuries (Kuala Lumpur: Islamic Arts Museum Malaysia, 2016); Frederike-Wiebke Daub, Formen und Funktionen des Layouts in arabischen Manuskripten anhand von Abschriften religiöser Texte: Al-Būṣīì̄s Burda, al-Ğazūlīs Dalāil und die Šifă’ von Qā Coran en Occident musulman du xe/Xvie à l' aube du Xıı/Xviı siècle. Les Daläil al-khayrāt d'al-Jazūlī," Journal of Qur'anic Studies 19, no. 3 (2017): 45-73; Sabiha Göloğlu, "Depicting the Islamic Holy Sites: Mecca, Medina, and Jerusalem in Late Ottoman Illustrated Prayer Books," in 15th International Congress of Turkish Art, ed. Michele Bernardini and Alessandro Taddei, with the collaboration of Michael Douglas Sheridan (Ankara: Ministry of Culture and Tourism, 2018). On commentaries on the Dalāil, see Guy Burak, "Prayers, Commentaries, and the Edification of the Ottoman Supplicant," in Historicizing Sunni Islam in the Ottoman Empire, c. 1450-c. 1750, ed. Tijana Krstić and Derin Terzioğlu (Leiden: Brill, 2020), 232-252. 


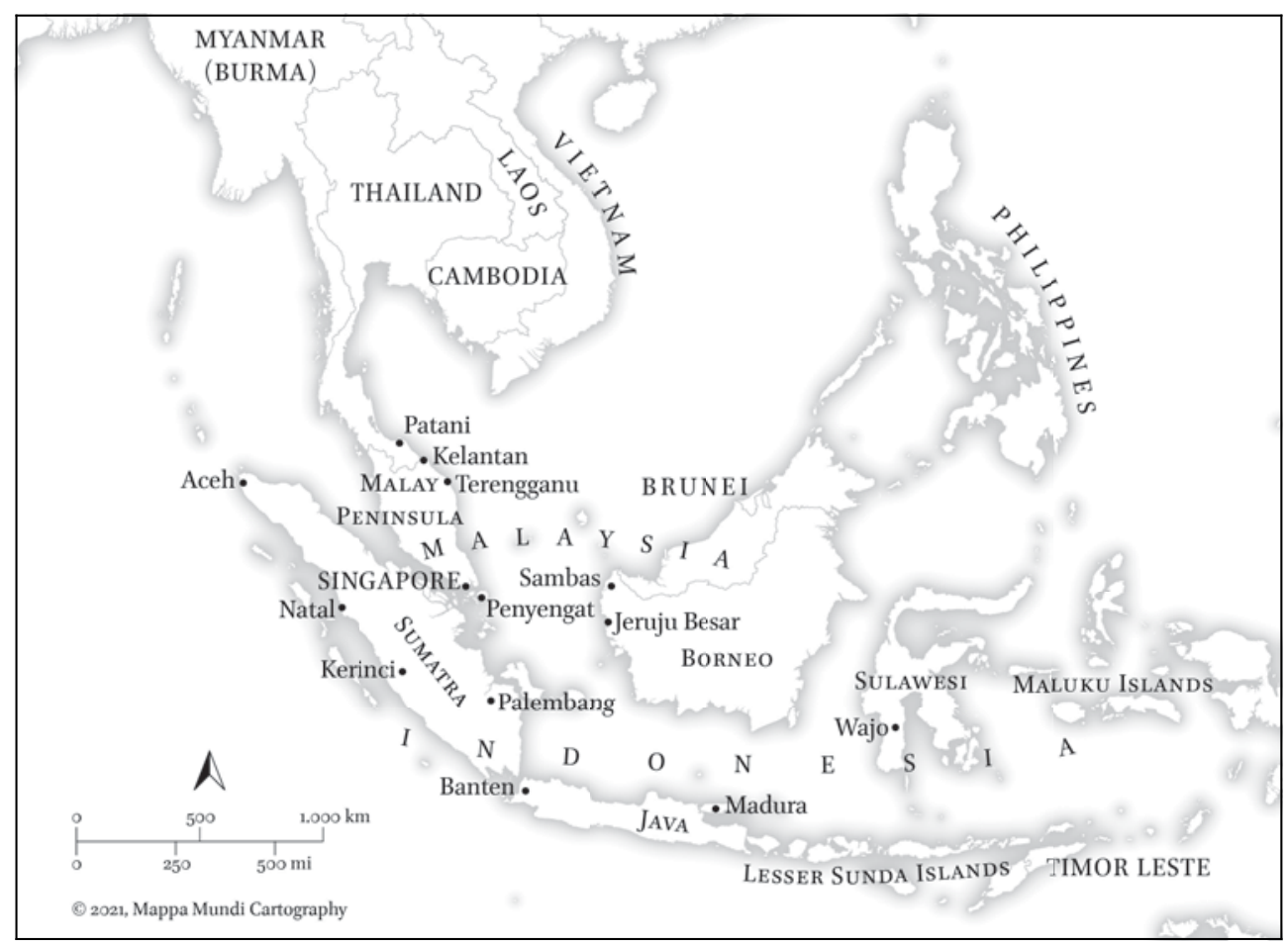

MAP 1 Map of Southeast Asia showing areas where manuscripts of the Daläil al-khayrāt have been produced or found

\section{The Dalä'il in Southeast Asia}

To date, the author is aware of at least 67 Daläil manuscripts from Southeast Asia, at least $5^{1}$ per cent of which are illustrated and/or illuminated (see Appendix). ${ }^{4}$ Many of the manuscripts do not have colophons, but identified places of production include Sumatra, the Malay peninsula, Java, Western Borneo, and South Sulawesi (see Map 1). Outside of Southeast Asia, a copy of the Dalā'il with a Malay colophon has been found in South Africa (it may have been produced by an Indonesian prisoner on Robben Island). ${ }^{5}$ No doubt there are further copies in public and private collections worldwide that have yet to be identified.

4 Many have not been published or inspected by the author to confirm whether they include illustrations and/or illumination.

5 Perpustakaan Negara Malaysia, Katalog Manuskrip Melayu di Afrika Selatan (Kuala Lumpur: Perpustakaan Negara Malaysia, 1998), 7, 13 and an unnumbered page. 
The manuscripts date from the eighteenth to the early twentieth century, in line with Southeast Asian manuscripts in general. It is rare to find books that were produced prior to this period, due to a number of factors including the hot and humid climate of the region, insects (such as termites), fire, and natural disasters. ${ }^{6}$ The lack of early copies of the Daläil means that it is difficult to ascertain its early history, transmission, and development in Southeast Asia.

The earliest known dated copies of the Daläil were produced in the 1140s/ 1730s. One, dated 1143/1730, was most likely copied in Sumatra, and is currently Ms Leiden, University Library, Or. 10.806 (Figure 1). ${ }^{7}$ The other, from Java, dated 1148/1736, is now Ms Kuala Lumpur, Islamic Arts Museum Malaysia, 1998.1.1623 (Figure 2). ${ }^{8}$ Both contain images of the rawda and minbar of the Prophet, demonstrating that illustrated manuscripts of the Daläil were present in the region from at least the early eighteenth century.

It is worth noting that Sufi devotional books were already circulating in Southeast Asia at least a century earlier. A manuscript from Aceh or Java of the Qașidat al-burda ("Ode of the Mantle") — a poem praising the Prophet composed by the Mamluk poet al-Būșīī (1211-1294) — containing an interlinear Malay translation, was already present in Europe by $1624 .{ }^{9}$ It is therefore possible that similar devotional works such as the Daläil were present in Southeast Asia much earlier than the manuscript evidence suggests.

The channels of transmission of the Daläil and other devotional texts into Southeast Asia, and the extent of their circulation in the region prior to the eighteenth and nineteenth centuries, are unclear. Nevertheless, they would have been linked to the development and practice of Sufism in the region. Islam began to be formally adopted by polities in northern Sumatra during the thirteenth century, subsequently spreading throughout the rest of Southeast Asia, particularly among the ports and urban centres, over the following three centuries. The presence of Sufi orders among these early Muslim communities and

6 For a brief discussion on the lack of, and evidence for, early manuscripts in Southeast Asia, see Farouk Yahya, "Introduction," in "Malay Manuscripts: A Guide to Paper and Watermarks. The Collected Works of Russell Jones 1972-2015," ed. Farouk Yahya, special issue, Indonesia and the Malay World 49 (144) (2021): 139--394.

7 Jan Just Witkam, Inventory of the Oriental Manuscripts of the Library of the University of Leiden (Leiden: Ter Lugt Press, 2002-2019), vol. 11, under Or. 10.806. See further discussion below.

8 Rusli, Daläil al-Khayrat, 98-101, cat. 26, figs. 52-53, and 124-125, fig. 68.

9 Cambridge University Library, Ll. 6. 25; see G.W.J. Drewes, Een 16de eeuwse Maleise vertaling van de Burda van al-Būsịrī ('s-Gravenhage: Martinus Nijhoff, 1955); Merle C. Ricklefs, Petrus Voorhoeve and Annabel Teh Gallop, Indonesian Manuscripts in Great Britain: A Catalogue of Manuscripts in Indonesian Languages in British Public Collections. New Edition with Addenda et Corrigenda (Jakarta: Yayasan Pustaka Obor Indonesia, 2014), 112. 


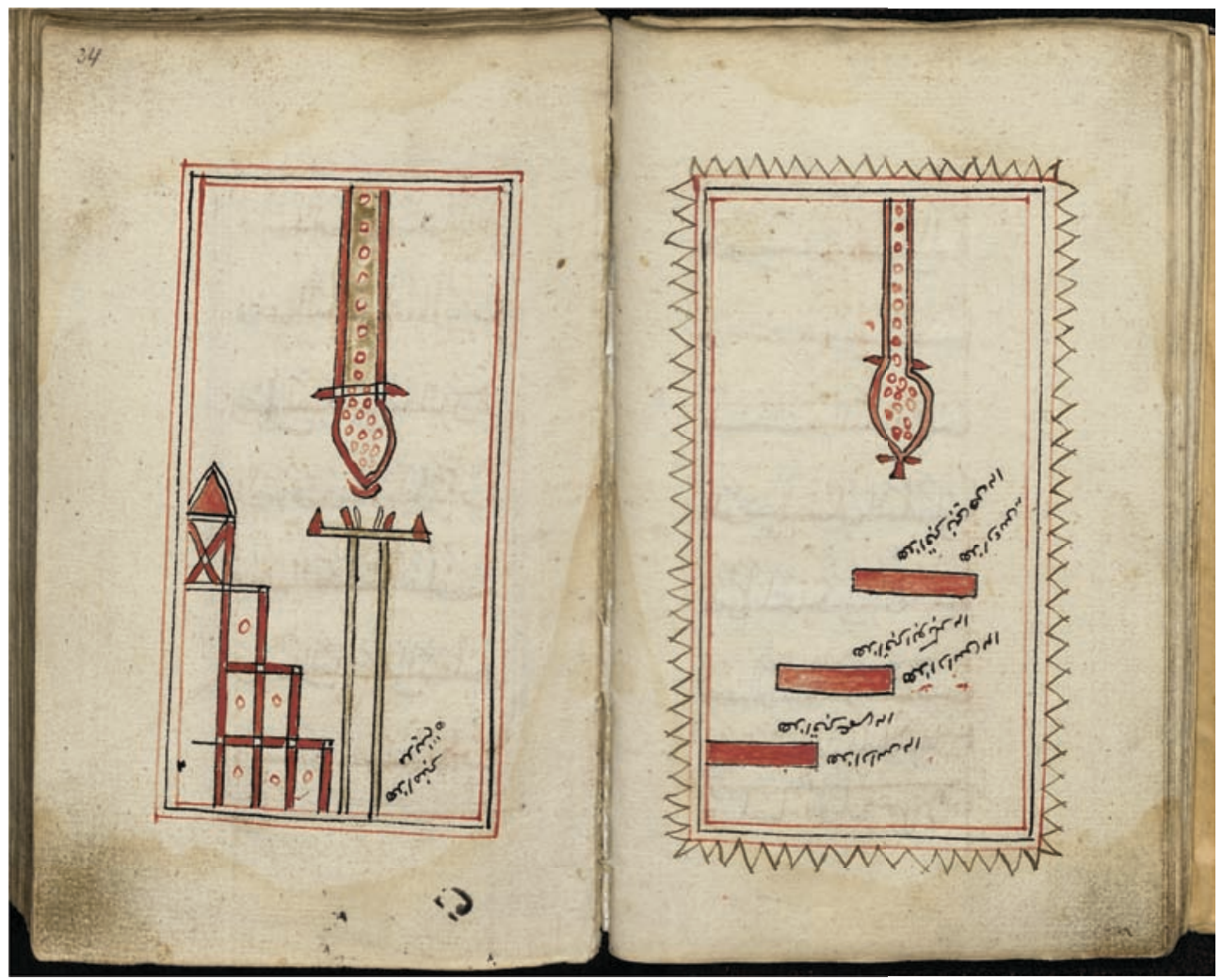

FIgURE 1 Raw MS LEIDEN, UNIVERSITY LIBRARY, OR. 10.806, FOLS. 33V-34R

networks is likely, but information about them is scarce due to the paucity of surviving historical records. ${ }^{10}$ It is only from the sixteenth century onwards that we have direct evidence of Sufism in the region, which was largely influenced by the teachings of scholars who had studied in Mecca and Medina. Among

10 It is unlikely, however, that the Islamisation of the region was due to Sufi influence, as previously thought. For a discussion on this issue, and for an overview of Sufism in Southeast Asia more generally, see Anthony H. Johns, "Islamization in Southeast Asia: Reflections and Reconsiderations with Special Reference to the Role of Sufism," Southeast Asian Studies 31, no. 1 (1993): 43-61; Martin van Bruinessen, "The Origins and Development of the Sufi Orders (Tarékat) in Southeast Asia," Studia Islamika -Indonesian Journal for Islamic Studies 1, no. 1 (1994): 1-23; Martin van Bruinessen, "Sufi 'Orders' in Southeast Asia: From Private Devotions to Social Network and Corporate Action," in Buddhist and Islamic Orders in Southern Asia: Comparative Perspectives, ed. R. Michael Feener and Anne M. Blackburn (Honolulu: University of Hawaii Press, 2018), 125-152. 


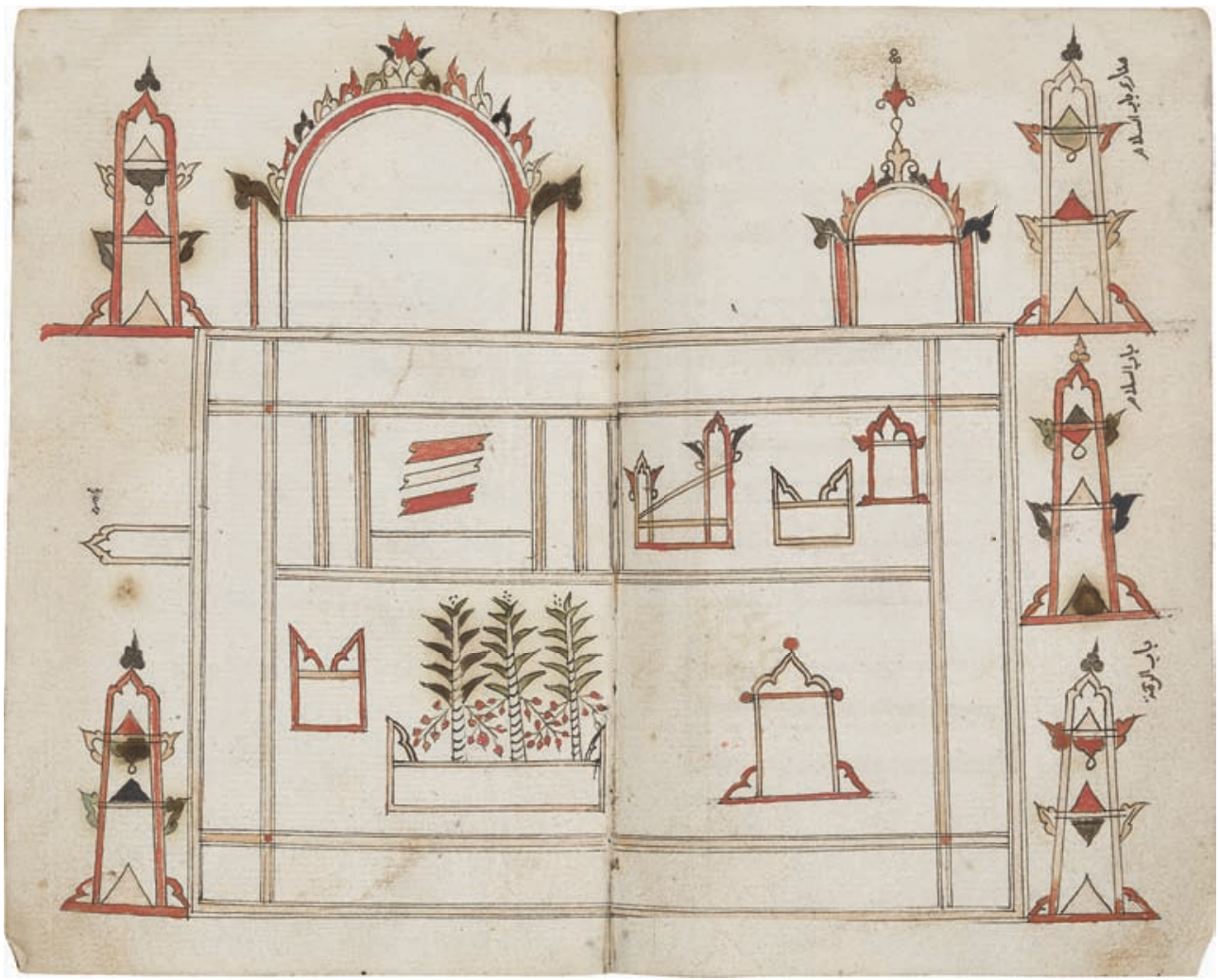

Figure 2 Raw

MS KUALA LUMPUR, ISLAMIC ARTS MUSEUM MALAYSIA, 1998.1.1623, FOLS. 56V-57R.

(C) ISLAMIC ARTS MUSEUM MALAYSIA

the most popular orders were the Shatțāriyya, the Khalwatiyya, and the Naqshbandiyya in the seventeenth and eighteenth centuries, and the Sammāniyya and the Qãdiriyya wa'l-Naqshbandiyya in the nineteenth century. ${ }^{11}$ Whether the Daläil can be linked to any particular order has yet to be investigated.

However, we know that the education of Hijaz-based scholars included learning the Daläill. For instance, in his bio-bibliography Kifāyat al-mustafid limā 'alā min al-asānīd, the Javanese scholar Muhammad Maḥfūz bin 'Abdillah al-Tarmusi (d. 1338/1920) records that he had learned the Daläil and received a licence (ijāza) from a shaikh at the Mosque of the Prophet in Medina. ${ }^{12}$ When

11 Van Bruinessen, "Sufi 'Orders' in Southeast Asia," 135.

12 Muhammad Mahfūz b. 'Abdillah al-Tarmusī, Kifāyat al-mustafì li-mā 'alā min al-asānìd (Beirut: Dār al-Bashāir al-Islāmiyya, 1987), 8, with a chain of transmission (isnād) for the Dalāil ending with al-Jazūlī on 36. On al-Tarmusī, see Martin van Bruinessen, "Mahfuz b. 
they returned to their homelands, these scholars often set up religious schools and spread what they had learned abroad locally. It is therefore not surprising to note that the areas where the majority of copies of the Daläil have been found (Aceh, Patani, Banten, etc.) were also centres of Islamic learning during the eighteenth to early twentieth century (see Map 1$).{ }^{13}$

While studying in the Hijaz, these scholars would almost certainly have come across and been influenced by local manuscript traditions, such as those prevalent in the core lands of the Ottoman Empire. This would certainly have had some impact on the development on the Southeast Asian manuscript tradition of the Daläil, both in terms of the textual contents and the choice and style of the images. An important piece of evidence for an Ottoman connection is a manuscript, MS 45807, now held at soAs University of London, which was copied in Sandıklı, Turkey and dated $1174 / 1760 .{ }^{14}$ It contains two illuminated headings in the Ottoman style and a double-page illustration of Mecca and Medina (fols. 15v-16r; Figure 3a). The flyleaf at the front of the manuscript contains a $d u\left({ }^{\prime} \vec{a}\right.$ for drinking water from the Zamzam well in Mecca. Of particular interest is that the Arabic text is accompanied by an interlinear Malay translation, written in a different hand and probably added later (Figure $3 b$ ). The history of this manuscript still requires further investigation, but it demonstrates that Ottoman copies of the Daläil were circulating among Southeast Asian communities, and would have been one of the routes for the transmission of the text and its images into Southeast Asia. Elements of Ottoman illumination styles can be found in some Southeast Asian copies of the Daläil, but

'Abd Allah Al-Tarmasi (K.H. Mahfudz Tremas, d. 1338/1920)," in Dictionnaire biographique des savants et grandes figures du monde musulman périphérique, du XIXe siècle à nos jours, Fasc. no. 1., ed. Marc Gaborieau et al. (Paris: CNRS-EH ESS, 1992), 30-31; Wan Mohd. Shaghir Abdullah, "Syeikh Mahfuz At-Tarmasi: Ulama Hadis Dunia Melayu," Utusan Malaysia, 13 June 2005. Republished online at: http://ulama.blogspot.com/2005/o6/syeikh-mahfuz -at-tarmasi.html. On the Kifayāt al-mustafid, see Abdul Malik Ghozali, "The Chains of Transmission of Syeikh Muhammad Mahfudz At-Tirmasi in Kifayāt al-mustafì," Heritage of Nusantara 7 , no. 1 (2018): 19-45.

13 See Heba Nayel Barakat and Nurul Iman Rusli, "The Royal Daläil al-Khayrāt Manuscript from Terengganu, Malaysia", in the present volume.

14 Adam Gacek, Catalogue of the Arabic Manuscripts in the Library of the School of Oriental and African Studies, University of London (London: School of Oriental and African Studies, 1981), 31, no. 50; Alison Ohta, "Front Binding and Case," in Objects of Instruction: Treasures of the School of Oriental and African Studies, ed. Anna Contadini (London: School of Oriental and African Studies, 2007, reprinted 2016), 108, cat. 85. The copyist was Mușțafā ibn 'Uthmān and it was completed on 29 Șafar 1174 (10 October 1760). I am grateful to Owen Wright for his help with the colophon. 


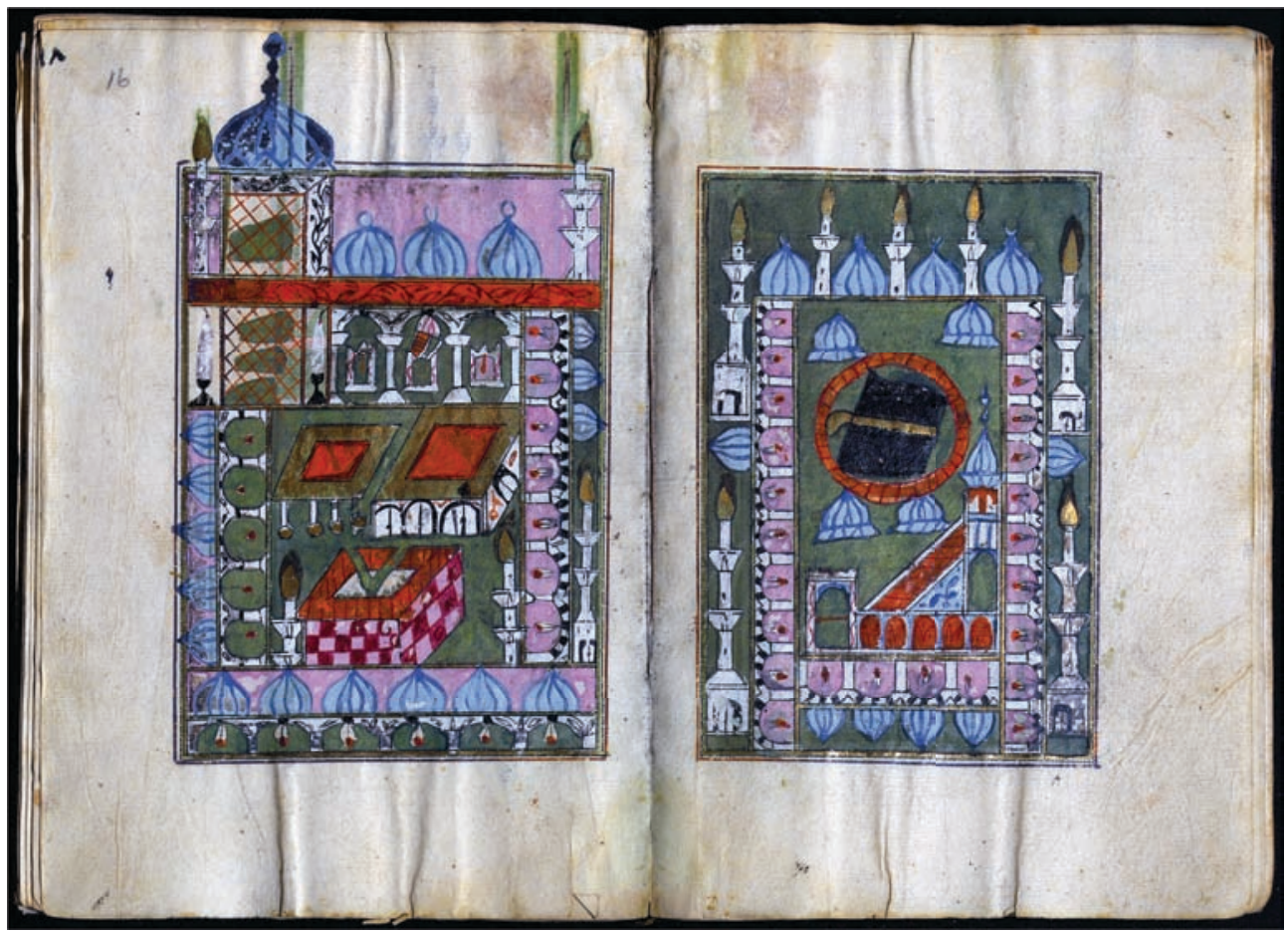

FIGURE 3A Mecca and Medina. Al-Jazūlī, Daläill al-khayrāt, copied in Sandıklı, Turkey, in 1174/176o MS LONDON, SOAS $45^{80} 7$, FOLS. $15 \mathrm{~V}-16 \mathrm{R}$. COURTESY OF SOAS

the common Ottoman three-dimensional renderings of Mecca and Medina are not found. Instead, the styles of the illustrations are largely derived from local artistic traditions, with perhaps some degree of Indian influence, as will be discussed below.

In Ms Jakarta, Perpustakaan Nasional Republik Indonesia, W. 295, the Dalä'il is followed by other texts, accompanied by interlinear Malay translations. They also include some numbers and headings in Turkish, and at the end there is a marginal note on. fol. 188v, in Malay, which reads:

Kemudian daripada ini semuanya Bahasa Turki, tiada seorang yang boleh mengetahui melainkan Allah

All is further on in Turkish, nobody understands it but Allah" ${ }^{15}$.

15 Translation by Ph.S. van Ronkel, Supplement to the Catalogue of the Arabic Manuscripts Preserved in the Museum of the Batavia Society of Arts and Sciences (Batavia: Albrecht \& Co.; The Hague: M. Nijhoff, 1913), 174. Many thanks to Sabiha Göloğlu for helping with this manuscript. 


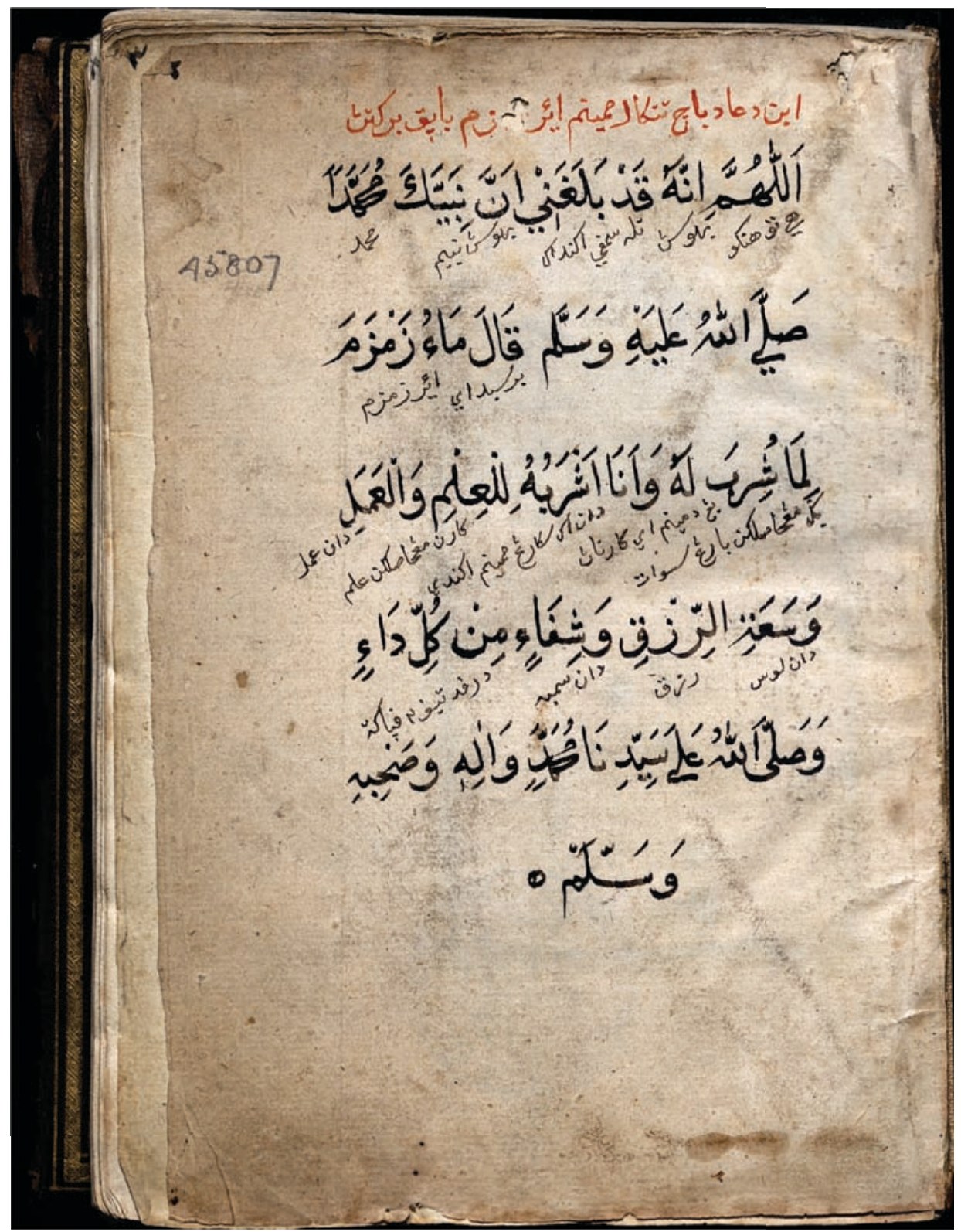

FIGURE 3в $\quad$ Du'ä’ for drinking Zamzam water with interlinear Malay translation. Al-Jazūlī, Daläil alkhayrät, copied in Sandıklı, Turkey, in 1174/1760 MS LONDON, SOAS 45807 , FLYLEAF. COURTESY OF SOAS 
It indicates that the scribe was copying the texts from a Turkish sourceproviding another clue to an Ottoman-Southeast Asian connection. The manuscript, dated 1228/1813, was from the collection of Hermann von de Wall (18071873), a German administrator-scholar who served the Dutch colonial government. Most of his manuscripts were collected in Riau where he was predominantly based.

A number of manuscripts reveal associations with the Hadhrami diaspora, who migrated from the Hadhramaut region in Yemen/South Arabia to various locations across the Indian Ocean, including Southeast Asia, particularly during the seventeenth to the early twentieth century. Their two highest social classes were the sayyid (who were descendants of the Prophet Muhammad) and the shaykh (who were not). Primarily affiliated to the 'Alawiyya order, by virtue of their birth the sayyid typically held religious authority within Hadhrami society. Their noble status was recognized in Southeast Asia and they often married into the local elite. ${ }^{16}$ Among the most prominent of the sayyid families in Southeast Asia were the al-'Aydarūs (also spelled al-Idrus), whose lineage can be traced to Abū Bakr al-'Aydarūs (d. 1508), the patron saint of Aden. ${ }^{17}$ As will be seen below, several of the Daläil manuscripts were copied or owned by sayyids of the al-'Aydarūs line.

Another Hadhrami connection can be seen in ms Kuala Lumpur, Perpustakaan Negara Malaysia, F B (A) 1027, which was donated to the library by Haji Fathil Bashir in $1984 .{ }^{18}$ This is almost certainly Fathil Basheer (1899-1994), grandson of Syeikh Omar Basheer (1811-1884), an important community leader in Penang during the nineteenth century. ${ }^{19}$ Their family was of Hadhrami

16 There have been many studies on the Hadhramis in Southeast Asia; some of the more recent include Ulrike Freitag, Indian Ocean Migrants and State Formation in Hadhramaut: Reforming the Homeland (Leiden: Brill, 2003); Engseng Ho, The Graves of Tarim: Genealogy and Mobility across the Indian Ocean (Berkeley, CA: University of California Press, 2006); Mohammad Redzuan Othman, "The Arabs Migration and Its Importance in the Historical Development of the Late Nineteenth and Early Twentieth Century Malaya," (paper presented at the 15th Annual World History Association Conference, Long Beach, California, 22-25 June 2006); Ahmed Ibrahim Abushouk and Hassan Ahmed Ibrahim, eds., The Hadhrami Diaspora in Southeast Asia:Identity Maintenance or Assimilation? (Leiden: Brill, 2009).

17 Ho, The Graves of Tarim, 5-6, 210.

18 Perpustakaan Negara Malaysia, Manuskrip Arab Koleksi Pusat Manuskrip Melayu (Kuala Lumpur: Perpustakaan Negara Malaysia, [no date]), unpaginated.

19 On Syeikh Omar Basheer, see Izrin Muaz Md Adnan, "A History of the Acheen Street Malay Enclave from Oral History Accounts," Journal of the Malaysian Branch of the Royal Asiatic Society 85, no. 1 (2012): 1-44, esp. 10-14. 
descent and it is perhaps worth noting that Omar Basheer was initiated into the Naqshbandiyya order. The role played by the local Hadhrami communities in the region, and the Indian Ocean network in general, in the practice and dissemination of the Daläil in Southeast Asia is something worth investigating in future research.

\section{$3 \quad$ Function and Usage}

The Daläil is a collection of blessings (șalawāt) upon the Prophet Muhammad, and it may be recited individually in private or in groups. Uttering șalawāt is not only an expression of one's piety and devotion towards the Prophet, but also rewards the practitioner with spiritual and worldly benefits. ${ }^{20}$ Perhaps of more direct relevance to the Dalā'il and included in al-Jazūli's preface of the text that might explain the wide circulation of the text in manuscript and printed forms, is the following saying by the Prophet regarding books of blessings:

Wa-qāla șalla’llāhu 'alaihi wa-sallam: Man șallā 'alayya fì kitābin lam tazali-l-malāikatu tuṣallì 'alaihi mādāma 'smì fi dhālika-l-kitāb.

And he said: Whoever blesses me in a book, the angels will not cease to bless him as long as my name continues in this book ${ }^{21}$

In Southeast Asia, the recitation of the Daläil was, and continues to be, practiced by various communities across the region. ${ }^{22}$ The practices in certain areas have idiosyncrasies that suggest that the rituals have been influenced by local traditions. The Daläil is particularly popular in Aceh, North Sumatra, where it is typically recited by groups of young men on Friday nights (malam

20 Marion Katz, The Birth of the Prophet Muhammad: Devotional Piety in Sunni Islam (Abingdon: Routledge, 2007), 76-80.

21 Abū 'Abdullāh Muḥammad ibn Sulaymān al-Jazūlī, Dalā'il al-khayrāt, published as Petunjuk Cara Memperoleh Syafaat Nabi sAw: Terjemah Dalailul Khairat, translated by Abdul Ghoni Asykur (Bandung: Husaini, 1997), 24. English translation adapted from Abū 'Abdullāh Muḥammad ibn Sulaymān al-Jazūlī, Guide to Happiness: A Manual of Prayer, trans. John B. Pearson (Oxford: Printed for private circulation, 1907), 8.

22 For a brief overview of the Dalāil in Southeast Asia, see M. Bagus Irawan. "Sanad Dalail Khairat di Nusantara." Iqra.id, 2 April 2020, available online at https://iqra.id/sanad-dalail -khairat-di-nusantara-219751/. See also Sabiha Göloğlu, 'In Writing and in Sound: The Dalä'il al-Khayrāt in the Late Ottoman Empire', in the present volume. 
Jumaat $)^{23}$ or during festivities and ceremonies such as mawlid celebrations and weddings. ${ }^{24}$ The recitations have a melodious quality and are accompanied by rhythmic body movements, and thus can be thought of as a form of performance art. ${ }^{25}$

Among the Minangkabau people of West Sumatra, the Daläil is closely associated with funeral rites. It is performed by troupes of young men on certain days following a person's death, at the home of the deceased, providing solace to the family. ${ }^{26}$ It was also recited at the graves of saints, accompanied by the beating of metal trays (talam). ${ }^{27}$

In Central and East Java, the reading of the Daläil is accompanied by a ritual of fasting known as Puasa Dalail Khairat ("The Fasting of the Daläil alkhayrāt"). This involves fasting for three years (except for certain days during which fasting is forbidden), while reciting the Daläil daily. The Puasa Dalail Khairat is preceded by a year of Puasa Dalail Qur'an, whereby the fasting is accompanied by reading one $j u z^{\prime}$ of the Qur'an per day. ${ }^{28}$ It is unclear when

23 Note that the day begins on the previous night, thus "Friday night" actually refers to Thursday night.

24 Mabrur, "Pudarnya Eksistensi Dalail Khairat di Negeri Syariat," Serambinews.com, 9 December 2018, available online at https://aceh.tribunnews.com/2018/12/o9/pudarnya-eksis tensi-dalail-khairat-di-negeri-syariat; Amiruddin (Abu Teuming), "Melestarikan Budaya Islami Dalail Khairat," Serambinews.com, 25 November 2019, available online at https:// aceh.tribunnews.com/2019/11/25/melestarikan-budaya-islami-dalail-khairat; see also Abdul Manan, The Ritual Calendar of South Acèh, Indonesia (Münster, Westfälische Wilhelms-Universität, 2015), 10, who reports of the Daläil being performed by men on Saturday nights, while women recite the Barzanji on Friday nights.

25 Nevertheless, the participants themselves do not see it as art, as observed by Margaret Kartomi, "The Development of the Acehnese Sitting Song-Dances and Frame-Drum Genres as Part of Religious Conversion and Continuing Piety," Bijdragen tot de Taal-, Land-en Volkenkunde 166, no. 1 (2010): 83-106: 9o.

26 Gazali, "Wisata Ziarah. Potensi Ekonomi Umat Di Lokasi Makam Syekh Moehammad Yoesoef Tilatang Kamang Kabupaten Agam," Suluah 14, no. 18 (2014): 43-48: 46; Haldi Patra, "Kelompok Shalawat yang Membaca Dalailul Khairat di Kecamatan Padang Tangah Payobadar Kota Payakumbuh." no date [c. 2017]. On the Daläil in West Sumatra, see also Apria Putra. "Senandung Negeri Seribu Shalawat. Dalā’il Khairat di Minangkabau dari Masa ke Masa." Surau Tuo, 13 November 2014, available online at http://surautuo.blogspot.com/ 2014/11/senandung-negeri-seribu-shalawat-dalail.html.

27 Hamka, Sejarah Islam di Sumatra (Medan: Pustaka Nasional, 1950), cited in Ediwar, Mohamed Anwar Omar Din, and Zulayti Zakaria, "Kesenian Bernuansa Islam Suku Melayu Minangkabau," Jurnal Melayu 5 (2010): 227-249.

28 Abdul Jalil, "Organisasi Sosial Dalāil Khairat (Studi Pengamal Dalāil Khairat K.H. Ahmad Basyir Kudus)," Inferensi 5, no. 1 (2011): 81-10o; Direktorat Jenderal Pendidikan Islam Kementrian Agama RI, Ensiklopedi Islam Nusantara. Edisi Budaya (Jakarta, Direktorat Jenderal Pendidikan Islam Kementrian Agama RI, 2018), 416; Melati Ismaila Rafici and Saifud- 
these fasting traditions began, but they evolved out of a wish to increase one's concentration when reciting the Daläil and the Qur'an. ${ }^{29}$

Apart from being part of Sufi devotional practice, the Daläil was also popular in times of hardship and war, such as during struggles against non-Muslim forces. ${ }^{30}$ Al-Jazūlì's composition of the text should be seen in the context of the Portuguese incursion into Morocco during the fifteenth century. ${ }^{31}$ There are indications that the Daläil was similarly involved in fights against European powers in Southeast Asia. During the eighteenth to early twentieth century, the Dutch and the British were expanding their power in the region. Some Daläil manuscripts from Aceh were confiscated by the Dutch from local resistance fighters as war booty. ${ }^{32}$ A prayer book containing the Dalāil, copied in 1229/1814 in Natal, West Sumatra, and now in Leiden University Library (Or. 1751), is said to have once belonged to Tuanku Imam Bonjol (1772-1864) (Figure 4). ${ }^{33} \mathrm{He}$ led the Padri movement, a group of radical Islamic reformers who were challenging the traditional establishments in the Minangkabau region, against the Dutch, and this manuscript was supposedly taken after battle in 1837 in which he was defeated by the Dutch.

The presence of the manuscripts among fighters indicates that they were carried on the person as apotropaic objects and for encouragement and strength. Indeed, there are historical accounts that mention the talismanic usage of the Daläil in battle. The Tuhfat al-nafis ("The Precious Gift"), a nineteenth-century Malay historical work, includes an account of the revered Bugis leader Raja Haji Fisabilillah of Riau (1727-1784). In 1784, he fought against the Dutch forces in Melaka on the Malay peninsula. According to the Tuhfat alnafis, as he ordered his troops to attack, he recited the Daläil. Later in the battle he charged against the Dutch soldiers holding a dagger in one hand and a copy of the Daläil in the other, but he was shot and died as a martyr. ${ }^{34}$

din Zuhri Qudsy, “Transmisi, Sanad Keilmuan dan Resepsi Hadis Puasa Dalāil Al-Khairāt,” Mutawatir 10, no. 1, (2020), 1-26.

29 Muhammad Abdul Kharis, "Puasa Dalail al-Qur’an dalam Perspektif Hadis (Studi Kasus di Pondok Pesantren Putra Darul Falah Jekulo Kudus)" (Undergraduate dissertation, Universitas Islam Negeri Walisongo, Semarang, 2017), 75.

3o Witkam, Vroomheid, 70-71; Witkam, "The Battle of the Images," 70.

31 Cornell, Realm of the Saint, 162-166.

32 Such as Ms Leiden University Library, Or. 7209 (3), taken as war booty in 1896; see Witkam, Inventory of the Oriental Manuscripts, vol. 8, under Or. 7209.

33 Witkam, Inventory of the Oriental Manuscripts, vol. 2, 233-235; Idem, "The Islamic Pilgrimage in the Manuscript Literatures of Southeast Asia," in The Hajj: Collected Essays, ed. Venetia Porter and Liana Saif (London: British Museum, 2013), 214-223: 220-221. Many thanks also to Mulaika Hijjas for her help with this manuscript.

34 Raja Haji Ahmad and Raja Ali Haji, Tuhfat al-Nafis, ed. Virginia Matheson (Kuala Lumpur: 


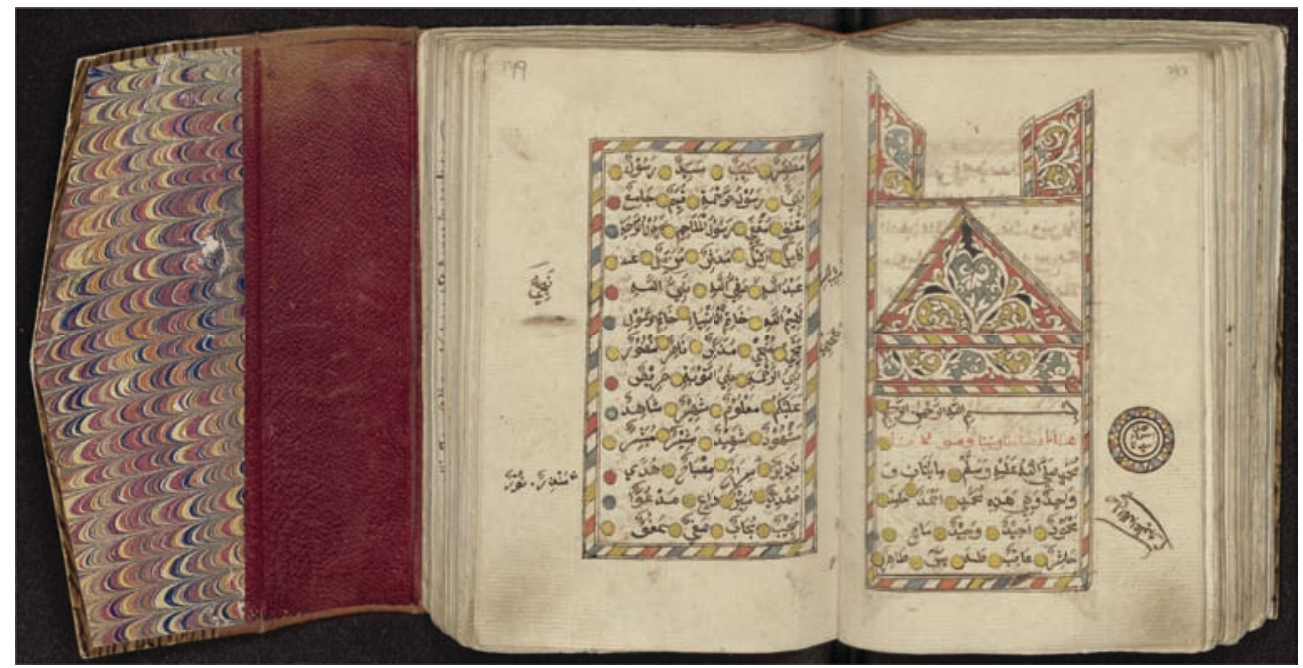

FIGURE 4 Illumination marking the start of the 201 names of the Prophet. Al-Jazūlī, Daläil al-khayrāt, in the prayer book of Tuanku Imam Bonjol, Natal, Sumatra, 1229/1814

MS LEIDEN, UNIVERSITY LIBRARY, OR. 1751, PP. 343-344

Similarly, during the Java War $\left(1825^{-1830}\right)$, the Daläil was one of the texts used to rally the Javanese troops in their fight against the Dutch. ${ }^{35}$

A number of manuscripts were copied or owned by royal patrons: Ms Leipzig, University Library, Gabelentz 52, from Palembang; ${ }^{36}$ Ms Jakarta, Perpustakaan Nasional Republik Indonesia, A. 78-A. 81, from Banten; and Ms Kuala Lumpur, Islamic Arts Museum Malaysia, 1998.1.26o7, from Terengganu (see below). ${ }^{37}$ They demonstrate an interest in the Daläil among the ruling elite of Southeast Asian society.

Fajar Bakti, 1982), 209. For a discussion of this event, see Ibrahim Alfian, "Dimensi Agama dan Reaksi Dunia Melayu Terhadap Penetrasi Barat di Abad Xvıı dan Xıx Khasnya di Riau, Melaka, Palembang, dan Aceh," Humaniora 1 (1989): 71-86: 71-79; Aswandi Syahri. "Kitab Dalāil al-Khayrat, Pegangan Raja Haji Dalam Melawan Belanda." Jantungmelayu, 28 June 2018, available online at https://jantungmelayu.com/2018/o6/kitab-dalail-al-khayrat-peg angan-raja-haji-dalam-melawan-belanda/.

35 Mualimbunsu Syam Muhammad, Motivasi Perang Sabil di Nusantara. Kajian Kitab Ramalan Joyoboyo, Dalailul-Khairat, dan Hikayat Perang Sabil (Jakarta: Media Madania, 2013), 180, footnote 8 (many thanks to Kevin Fogg for help with this reference).

36 See Beate Wiesmüller, "Von Istanbul nach Palembang: Die unerschlossenen islamischen Handschriften der Universitätsbibliothek," in Das Buch in Antike, Mittelalter und Neuzeit. Sonderbestände der Universitätsbibliothek Leipzig, ed. Thomas Fuchs, Christoph Mackert and Reinhold Scholl (Wiesbaden: Harrassowitz, 2012), 281-303. Many thanks to Annabel Teh Gallop for this reference.

37 See Barakat and Rusli, "The Royal Dalä̀il al-Khayrāt", in the present volume. 
The textual contents and structure of Southeast Asian Daläil manuscripts are similar to those from other parts of the Islamic world. The core text of the Dalà'il consists of the following:

1. A preface or introduction by al-Jazūlī in which he discusses the title and aims of the book, followed by the benefits of reciting blessings upon the Prophet.

2. A list of the Prophet's 201 names.

3. Description of the Prophet's tomb and those of his two successors, Abū Bakr and 'Umar. In the text, the tombs are referred to as the rawda (garden). ${ }^{38}$

4. The main text of the Daläil. This is divided into eight sections known as hizb, with each one containing prayers to be recited on a specific day of the week. Typically, the sequence runs from Monday to the following Monday. Apart from being divided into eight daily sections, the text can also be split into Quarters, Thirds, and Halves. These are thought to be relics of an earlier type of division of the text. ${ }^{39}$

Additional elements may be added before or after this core text, such as various $d u^{\prime} \bar{a}^{\prime}$ (supplications) and the chain of transmission of the Dalāil (isnād) (found in Ms Kuala Lumpur, Islamic Arts Museum Malaysia, 1998.1.26o7, and Ms Kuala Lumpur, Perpustakaan Negara Malaysia, Mss 3793). These additional elements may differ between copies of the Dalä'il. However, in two manuscripts, the main text of the Dalā'il is followed by a series of șalawāt, $d u^{\prime} \bar{a}^{\prime}$, magical prescriptions and divinatory techniques, including a $7 \times 7$ Latin square containing the symbols known as the Seven Seals of Solomon (Ms Paris, Bibliothèque nationale de France, Mal-Pol 109, fol. 123v; and Ms Leipzig, University Library, Gabelentz 52, fol. $163 \mathrm{v}){ }^{40}$ This indicates some sort of relationship between the two copies, and they could perhaps be traced to a common source.

38 The 201 names and the description of the tombs (alongside its accompanying illustrations) help to identify a particular text as the Dalä'il, and to distinguish it from other prayers or blessings to the Prophet. In addition, as they are normally located towards the beginning of the text, they are a good way of orientating the researcher around the Daläil, especially if there are various $d u^{\prime} \mathfrak{a}^{\prime}$ at the beginning of the text.

Alexander G. Ellis, "Translation of the Introduction Prefixed to the Dalâil al-khayrât in the Edition Lithographed in Cairo in A.H.1281 (A.D.1864)," in al-Jazūlī and Pearson, Guide to Happiness, 73-76: 74-75; Witkam, Vroomheid, 58; Witkam, "The Battle of the Images," 69.

40 On the Seven Seals of Solomon, see Farouk Yahya, Magic and Divination in Malay Illustrated Manuscripts (Leiden: Brill, 2016), 198-201. 
The core text of the Dalāil itself may vary between copies. From the list of the 201 names of the Prophet, we can see that there are at least two recensions of the text. Often, the names end with Șạhib al-faraj ("Master of Joy"), but there are also manuscripts in which the list ends with Karim al-makhraj ("Noble of Ending"). ${ }^{41}$ By grouping the manuscripts by the names they contain, we may plot their geographical and temporal distribution to see if they could help clarify any patterns of transmission and circulation of the Dalāil in the region.

\section{$5 \quad$ Translations into Local Languages}

An important development of the text in Southeast Asia was its translation into local languages such as Malay and Javanese.

We find manuscripts of the Daläil being translated into other languages in other parts of the Islamic world; for instance, there are Kashmiri copies with interlinear Persian translations. ${ }^{42}$ Several Southeast Asian manuscripts contain interlinear Malay translations in Jawi script (Malay in Arabic script), including Ms Kuala Lumpur, Perpustakaan Negara Malaysia, Mss 2586, most likely copied in Terengganu, dated $1256 / 1840$ (Figure 6).$^{43}$ According to the colophon, it was copied by Syed Ahmad ibn Syed Muhammad al-Idrus (d. 1315/1897; also known as Tok Ku Malaka). He belonged to the al-'Aydarūs family, who, from

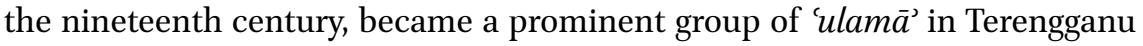
and were closely involved with the religious affairs of the sultanate. ${ }^{44} \mathrm{Al}$-Idrus had spent time in Mecca and was the author of several religious works. ${ }^{45}$

41 Translations of names based on Rifaat Y. Ebied and M.J.L. Young, "A List of the Appellations of the Prophet Muhammad," The Muslim World 66, no. 4 (1976): 259-262. The two manuscripts are Ms Kuala Lumpur, Perpustakaan Negara Malaysia, MSS 1273, Patani, nineteenth century (fol. 13v), and Ms Kuala Lumpur, Perpustakaan Negara Malaysia, Mss 2996, Malay peninsula or Sumatra, nineteenth century (fol. 19v).

42 For instance, an eighteenth-century Kashmiri manuscript, Ms Kuala Lumpur, Islamic Arts Museum Malaysia, 2012.11.29, contains an interlinear Persian translation; see Nurul Iman, Daläil al-Khayrat, $78-79$, cat. 18.

43 Perpustakaan Negara Malaysia, Katalog Manuskrip Melayu. Koleksi Perpustakaan Negara Malaysia. Tambahan Pertama (Kuala Lumpur: Perpustakaan Negara Malaysia, 2001), 127; Annabel Teh Gallop, "Seni Hias Manuskrip Melayu," in Warisan Manuskrip Melayu (Kuala Lumpur: Perpustakaan Negara Malaysia, 2002), 239-259: 241, fig. 145, and 253, fig. 16 o.

44 On the al-Idrus family in Terengganu, see Mohammad Redzuan Othman, "The Arabs Migration," 9-11.

45 For his life and works, see Aladin Hj. Mamat, "Ulama Golongan Syed di Terengganu. Peranan dan Sumbangan dalam Perkembangan Islam," (PhD thesis, Universiti Malaya, 2013), 226-249. 
In this manuscript he did not merely copy the Daläil but appears to have also been its translator. ${ }^{46}$

The Malay translation appears underneath the Arabic text. The title of the work, Dalāil al-khayrātwa-shawāriq al-anwār fì dhikr al-șalawāt 'ala al-nabīyyi al-mukhtār, has been translated (word for word, rather than idiomatically) as: Segala dalil / segala kebajikan / dan segala benda dan / segala cahaya / pada / menyatakan / selawat / atas nabi / yang dipilih ("All proofs / all goodness / and all things and / all lights / on / saying / blessings / upon the prophet / who was chosen") (fol. iv). The tombs of the Prophet and his Companions, referred to in Arabic as rawda (garden), has been translated as kebung (i.e. kebun, garden) (fol. 16r).

Two other manuscripts in the Perpustakaan Negara Malaysia also contain interlinear Malay translations, and they both appear to have a connection to alIdrus or his family. Ms Kuala Lumpur, Perpustakaan Negara Malaysia, Mss 2368 was copied in Singapore in 1298/1881 (Figure 10), ${ }^{47}$ while Ms Kuala Lumpur, Perpustakaan Negara Malaysia, Mss 3793 was probably copied in Jeruju Besar, western Borneo, and dated 1310/1892 (Figure 11). ${ }^{48}$ The interlinear Malay translations in the two manuscripts are almost identical, and both copies also have similar single-page illustration of the tombs. The colophon of ms Kuala Lumpur, Perpustakaan Negara Malaysia, Mss 2368 notes that Syed Ahmad alIdrus was one of the copyists, ${ }^{49}$ and that he had verified it (ditashihkannya) and translated it into Malay "so that it will benefit those who do not know Arabic" (itu supaya boleh mengambil manfaat dengan dia oleh segala orang yang tiada mengetahui mereka itu dengan Bahasa Arab) (fol. 127r). The Malay translation in these two manuscripts slightly differs from that of the Terengganu manuscript, with more of the original Arabic text preserved. For instance, the tombs are referred under their Arabic term, rawda.

The Jeruju Besar manuscript, ms Kuala Lumpur, Perpustakaan Negara Malaysia, MSs 3793 contains additional material that is not found in the Singapore copy, MS Kuala Lumpur, Perpustakaan Negara Malaysia, Mss 2368, such as a chain of transmission of the Daläil ending with al-Jazūlì (fol. 6r). Its colophon $($ fol. $6 \mathrm{v})$ provides ownership notes with the names of two people also with the

\footnotetext{
46 Syed Hadzrullathfi Syed Omar, et al., "Works by Terengganu's Scholars of the 19th Century in Dignifying the Study of Islamic Knowledge Based on the al-Qur'an," Asian Social Science 10 (2014): 128-136: 133 .

47 Perpustakaan Negara Malaysia, Katalog Manuskrip Melayu. Koleksi Perpustakaan Negara Malaysia (Kuala Lumpur: Perpustakaan Negara Malaysia, 200o), 83-84.

48 Perpustakaan Negara Malaysia, Katalog Manuskrip Melayu: Koleksi Perpustakaan Negara Malaysia. Tambahan Kelima (Kuala Lumpur: Perpustakaan Negara Malaysia, 2008), 103.

49 The main copyist was a certain Haji Muhammad Khafi bin Marhum Haji Sulaiman.
} 
surname al-Idrus. ${ }^{50}$ Their identities and relationship with Syed Ahmad al-Idrus are still unclear.

There is at least another copy of the Daläil with an al-Idrus connection. The colophon of Ms Kuala Lumpur, Islamic Arts Museum Malaysia, 1998.1.26o7, most probably copied in Terengganu and dated 1250/1835, contains the name of al-Idrus's cousin, Syed Muhammad ibn al-Marhum Zainal Abidin al-Idrus (also known as Tok Ku Tuan Besar, d. 1295/1878), with a chain of transmission ending with al-Jazūlī. ${ }^{51}$ Educated in Mecca, Syed Muhammad al-Idrus was one of the most prominent religious scholars in Terengganu. ${ }^{52}$ This Daläil manuscript contains illuminations and illustrations painted in gold, suggesting that it was produced for a royal patron..$^{53}$

One manuscript from Java (MS London, British Library, Io Islamic 2939), dateable to the eighteenth-nineteenth century, contains an interlinear Javanese translation in Pegon script (Javanese in Arabic script). ${ }^{54}$

\section{$6 \quad$ Illumination}

Illumination in Southeast Asian Daläil manuscripts serves not only to beautify them, but also to mark sections of a text, particularly those that are deemed important. These typically include the introduction to the text, the beginning of the section on the 201 names of the Prophet (Figure 4), and the beginning of the recitations for the first Monday (Figure 6). Although the division of the Dalāil into eight daily sections may be marked within the manuscripts, often more prominence is given to the textual divisions of Quarters, Thirds, and Halves, which may receive more elaborate forms of decoration (Figure 5$).{ }^{55}$ This might relate to the higher level of spirituality attributed to a reader who reads the Dalä'il in four, three, or two parts, or even the whole book in one go. ${ }^{56}$ That said, daily divisions are not ignored and are still noted in the manuscripts, but

50 Syarif Ibrahim bin Uthman bin Alwi bin Abdul Rahman bin Idrus bin Abdul Rahman alIdrus (with the date $12 \mathrm{Rabī}^{`}$ al-awwal 1310/4 October 1892), and later in pencil Syarif Alwi bin Syarif Yusuf al-Idrus.

$5^{1} \quad$ Rusli, Daläil al-Khayrat, 92-93, cat. 24, fig. 49, and 143, fig. 93.

$5^{2}$ On his life and works, see Aladin, "Ulama Golongan Syed di Terengganu," 250-271.

53 Rusli, Daläil al-Khayrat, 93.

54 I am grateful to Annabel Teh Gallop and Michael Erdmann for bringing this to my attention.

55 Farouk Yahya, "A Dalāil Al-Khayrāt Manuscript in the Perpustakaan Negara Malaysia (MSS 1273)," (MA thesis, soAs University of London, 2006), 66-67.

56 Ellis, "Translation of the Introduction," $74-75$. 


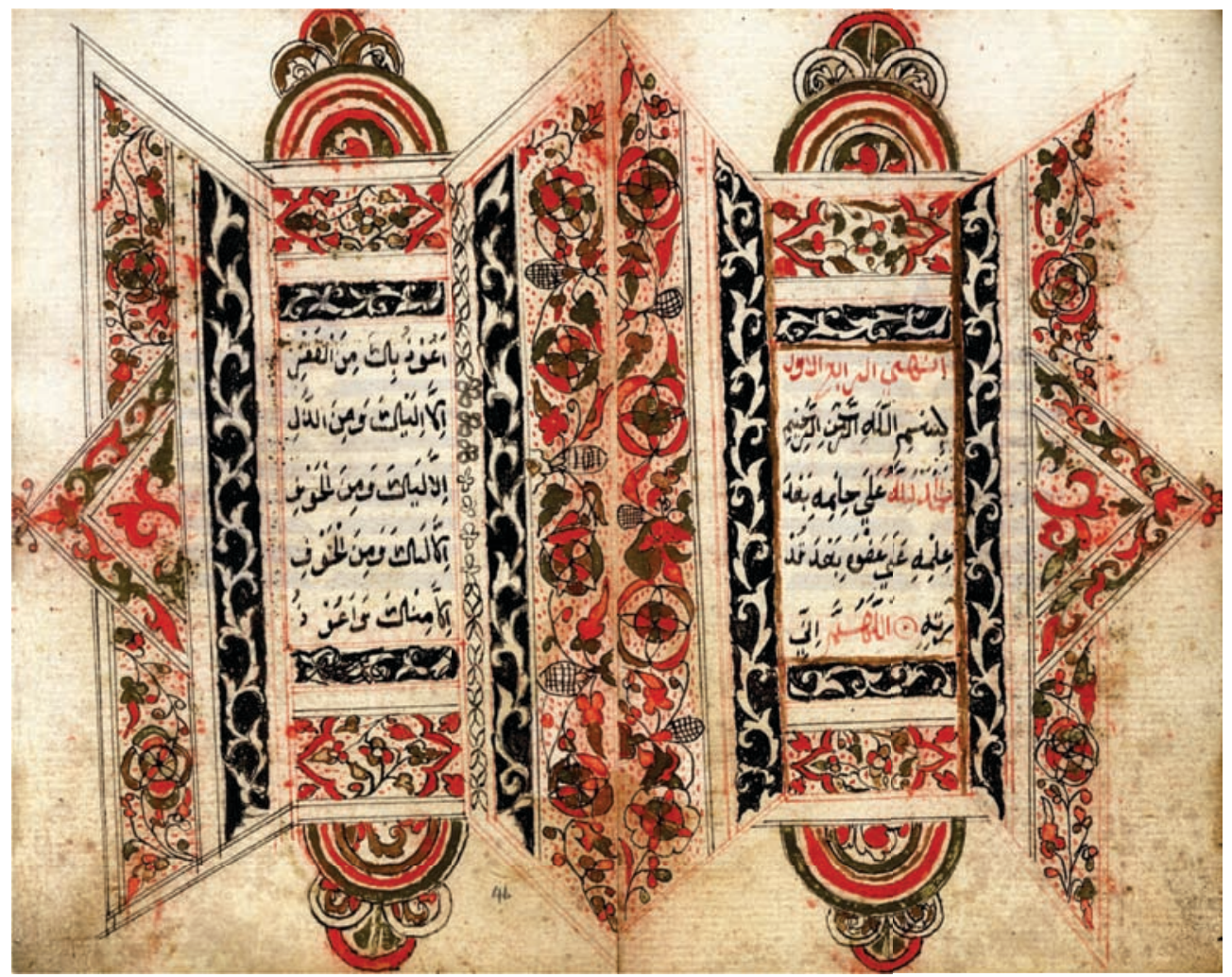

FIGURE 5 Double-page illumination marking the start of the second Quarter. Al-Jazūlī, Dalāil alkhayrāt, probably Sambas, early nineteenth century

MS KUALA LUMPUR, PERPUSTAKAAN NEGARA MALAYSia, MSS 2996, FOLS. 45V-46R. COURTESY OF PERPUSTAKAAN NEGARA MALAYSIA

the decorative devices used to mark them are on a smaller scale and much less frequent. ${ }^{57}$

In general, the illumination styles borrow from the decorative repertoire used for Southeast Asian Qur'ans. These include the use of double-page illuminated frames and single headpieces, done in distinctive regional styles. ${ }^{58}$ This enables us to assign a geographical origin to a manuscript when the colophon lacks such information.

57 Farouk Yahya, "A Dalāil Al-Khayrāt Manuscript," 66-67.

58 On the various regional illumination styles of Southeast Asian Qur'ans, see Annabel Teh Gallop, "Islamic Manuscript Art of Southeast Asia," in Crescent Moon: Islamic Art \& Civilisation in Southeast Asia, ed.James Bennett (Adelaide: Art Gallery of South Australia, 2005), $15^{8-189 .}$ 


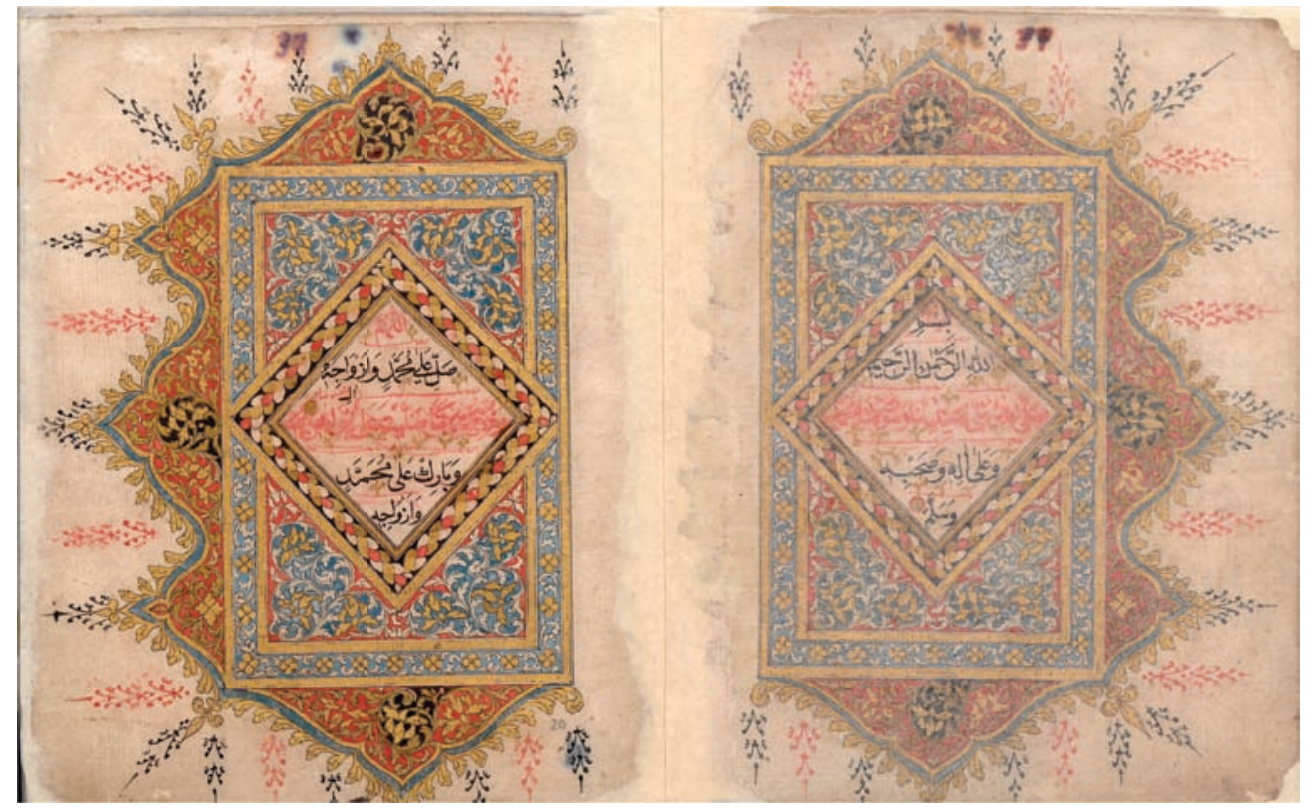

FIGURE 6 Double-page illumination marking the start of the first Monday recitations. Al-Jazūlī, Daläil al-khayrāt, Terengganu, 1256/1840

MS KUALA LUMPUR, PERPUSTAKAAN NEGARA MALAYSIA, MSS 2586, FOLS. 19V-20R. COURTESY OF PERPUSTAKAAN NEGARA MALAYSIA

The Syed Ahmad al-Idrus manuscript, ms Kuala Lumpur, Perpustakaan Negara Malaysia, MSs 2586, for instance, is beautifully illuminated in the Terengganu style, with the use of gold, black, red, light blue, and "reserved white" (uncoloured parts of the paper). The beginning of the recitations for the first Monday are decorated with an illuminated double-page (fols. 19v-2or; Figure 6). The arches on all three sides of the text block are linked with a continuous outline, with V-shaped finials emanating from the edges. Gold is one of the main colours used. These features are characteristic of the Terengganu style of manuscript illumination, commonly appearing in Qur'ans from the area. ${ }^{59}$

Other sections of the manuscript are also illuminated. The beginning or end of a Quarter, Third, and Half are marked by decorative inscription bands. In contrast, apart from the start of the recitation for Tuesday (fol. 27r) and the end of Thursday (fol. 49r), the markers for the other days are not decorated.

59 Annabel Teh Gallop, "The Spirit of Langkasuka? Illuminated Manuscripts from the East Coast of the Malay Peninsula," Indonesia and the Malay World 33 (2005): 113-182: 116-117. 


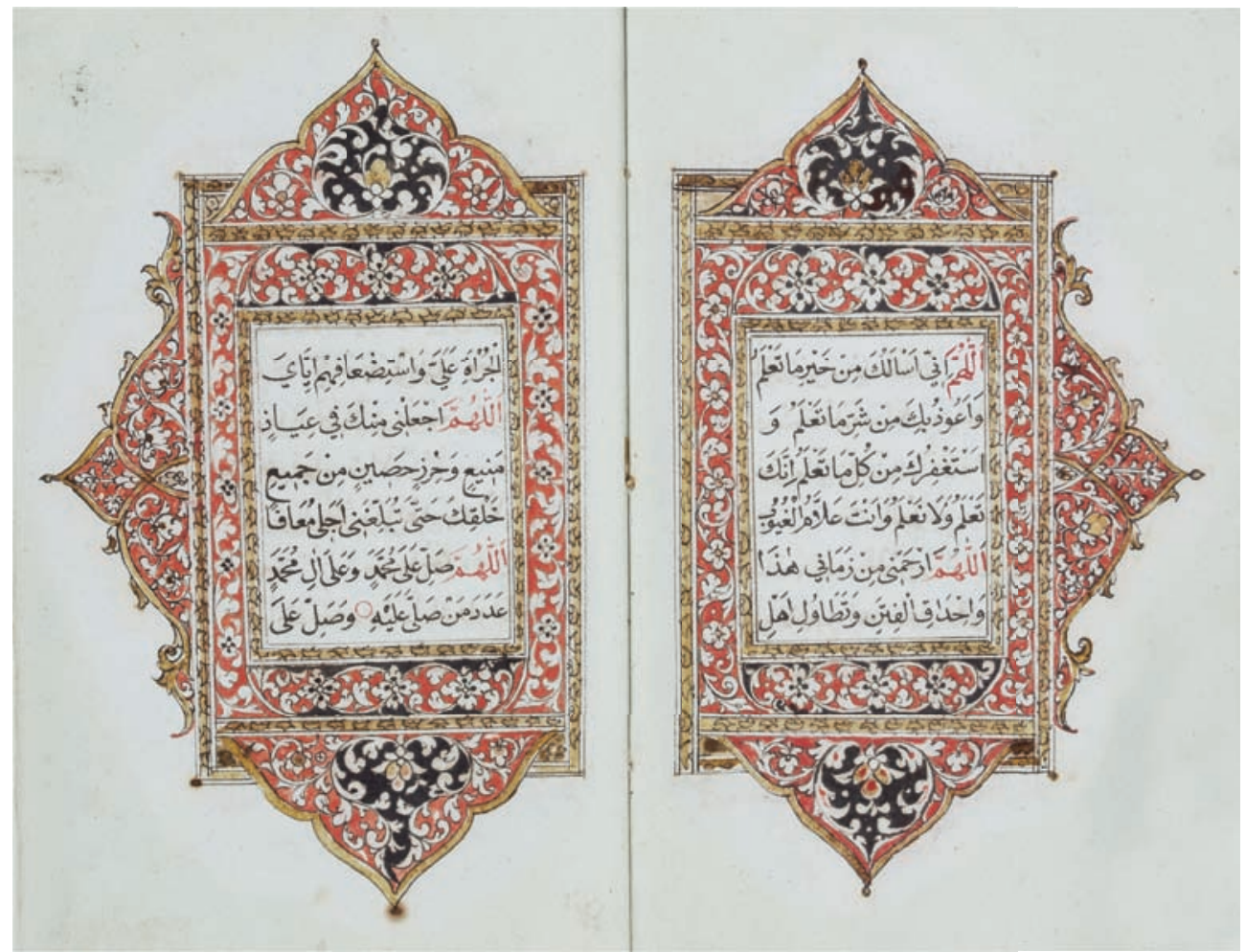

FIGURE 7 Double-page illumination marking the start of the Tuesday recitations. Al-Jazūlī, Dalāil al-khayrāt, probably Patani or Kelantan, nineteenth century

MS KUALA LUMPUR, ISLAMIC ARTS MUSEUM MALAYSIA, 1998.1.79O, FOLS. 2OV-21R. (C) ISLAMIC ARTS MUSEUM MALAYSIA

One manuscript in which the daily divisions are given greater prominence is Ms Kuala Lumpur, Islamic Arts Museum Malaysia, 1998.1.79o, probably from Patani on the Malay peninsula, dateable to the nineteenth century (Figure 7) ${ }^{60}$ In this manuscript, the beginning of the recitations for the first Monday, Tuesday, Wednesday, Thursday, and Friday are given illuminated double-frames or headpieces. ${ }^{61}$ The decoration is in the Patani style, characterized by an interlocking wave motif on the side arch emanating from the text block, particularly in the illuminated double-frame surrounding the start of Tuesday's recitations (fols. 2ov-21r). ${ }^{62}$ It is also worth noting that in another set of illuminated dou-

6o Rusli, Dalä'il al-Khayrat, 94-97, cat. 25, figs. 50-51, and 142, fig. 92.

61 Those for the remaining days are not decorated.

62 Gallop, "The Spirit of Langkasuka?," 117-120. 
ble frames within this manuscript (fols. 12v-13r), ${ }^{63}$ "the half-arch at the top and bottom of each facing page which meet as if in the spine to form a full arch" is a style found in Indian Qur'ans but not in Southeast Asia. ${ }^{64}$

Yet, it must also be emphasized that people, books, and designs travel, and thus a manuscript decorated with a particular regional style might not necessarily have been produced in that same region. For instance, the illumination in a Daläil now in the Balai Maklumat Kebudayaan Melayu Riau, located on the island of Penyengat in the Riau Archipelago, reveals influence of the Terengganu style but with certain unusual features. These features are similar to those found in a Qur'an dated 1867 copied by Abdurrahman Stambul of Penyengat (now in the Masjid Raya Sultan Riau, Penyengat), thus constituting a small group of a variant of the Terengganu style. ${ }^{65}$

Furthermore, while illumination styles in Southeast Asian Qur'ans are fairly conservative (i.e. they do not deviate too much from basic prototypes), those in the Daläil (as well as in manuscripts of the kitab maulid; see below) are less bound by such restrictions and can be a bit more varied. We thus find more examples of artists using existing stylistic conventions to generate new designs. ${ }^{66}$

\section{The Illustrations}

As Jan Just Witkam has observed, within the Islamic world manuscripts of the Dalāil would often be illustrated in one of three ways:

- An illustration of the three tombs (rawda) on a single page;

- A double-page illustration, with one page (usually the right) showing the tombs, and the other depicting the pulpit of the Prophet in Medina;

- A double-page illustration with a general view of Mecca and Medina (usually with Mecca on the right and Medina on the left). ${ }^{67}$

63 Rusli, Dalä'il al-Khayrat, 94-95.

64 Annabel Teh Gallop, pers. comm. 18 June 2011.

65 Annabel Teh Gallop, "Palace and Pondok: Patronage and Production of Illuminated Manuscripts on the East Coast of the Malay Peninsula," in Warisan Seni Ukir Kayu Melayu / Legacy of the Art of Malay Woodcarving, ed. Zawiyah Baba (Bangi: Institut Alam dan Tamadun Melayu, University Kebangsaan Malaysia, 2010), 143-162: 155-157; see also Mohd. Zahamri Nizar, "Dari Patani ke Riau-Lingga. Kajian Iluminasi Manuskrip Dalail-al-Khayrat Pulau Penyengat," in Prosiding Persidangan Antarabangsa Manuskrip Melayu 2017 (Kuala Lumpur: Perpustakaan Negara Malaysia, 2017), 17-35. Many thanks to Annabel Teh Gallop for sharing images of this manuscript with me.

66 Annabel Teh Gallop, pers. comm. 18 June 2011.

67 Witkam, Vroomheid, 71-92; Witkam, "The Battle of the Images," 71-75. 
All three types are found among Southeast Asian manuscripts, but the styles are quite different to those from other parts of the Islamic world, as is their approach to spatial organization. At present, it is difficult to draw any conclusion on geographical or chronological trends regarding the distribution of these three types in Southeast Asia. Nevertheless, a number of other preliminary observations on the illustrations can be made.

Firstly, although these illustrations accompany the textual description of the tombs of the Prophet and his Companions, the placement of the images changes from manuscript to manuscript, and they are not necessarily placed within the exact passage of text. For instance, in the majority of cases they are positioned in the middle of the description of the tombs, but in a few instances they are placed immediately before or after the description.

Secondly, the illustrations incorporate local artistic styles and have connections with other media such as architecture, woodwork, and textiles. ${ }^{68}$ Objects, buildings, and landscape elements are depicted with limited use of perspective, shading, or depth - common characteristics of traditional Southeast Asian paintings in general. Thus, the bird's-eye view of Mecca and Medina, where the two sanctuaries are depicted in linear perspective-so common among Ottoman images from the eighteenth century onwards-are never found in Southeast Asia. ${ }^{69}$ Another feature of the Southeast Asian visual idiom is that "refined" human beings (such as deities, princes and heroes) are typically depicted in a highly stylized way to conform to an aesthetic ideal, in contrast to those who are "coarse", who are depicted in a more naturalistic manner. What merits further investigation is whether a similar hierarchy also applies to buildings, as that could explain the sometimes highly ornamental and stylized depictions of sacred structures and objects found in some Southeast Asian Dalāil manuscripts (Figure 12a).

Finally, many of the illustrations are rather idiosyncratic in terms of their composition and style. ${ }^{70}$ Nevertheless, there are a few that can be placed together in groups based on various similarities, as will be seen below. An analysis of these groups would be very helpful in tracing the development of the Daläil within the region, and is something that is explored in this paper.

68 See Barakat and Rusli, "The Royal Dalāil al-Khayrāt", in the present volume.

69 On this style of painting, see Bill Hickman, "Note on a Nineteenth Century Painting of the Sacred Precinct in Mecca," in "Other Places: Ottomans Traveling, Seeing, Writing, Drawing the World," edited by Gottfried Hagen and Baki Tezcan, special double issue of Journal of Ottoman Studies / Osmanlı Araştırmaları 39 (2012): 17-28 (I am grateful to Simon O'Meara for this reference); Deniz Beyazit, "Defining Ottoman Realism in the Uppsala Mecca Painting," Muqarnas 37 (2020): 209-245.

Farouk Yahya, "A Dalä'il Al-Khayrāt Manuscript," 76. 
Al-Jazūlī's preface to the Dalāil includes a tradition that describes how the two Right-guided caliphs, Abū Bakr and 'Umar ibn al-Khațāb were buried next to the Prophet. ${ }^{71}$ The Malay translation of the passage, as found in Mss 2368 in the Perpustakaan Negara Malaysia (Singapore, 1298/1881), reads as follows:

Seperti demikian itulah menyebutkan dia oleh 'Urwa ibn al-Zubayr radiallāhu 'anhū berkata: ia ditanamkan Rasulullah șallā allāh 'alaihi wa-sallam pada tempatyang lapan $[g]$, dan ditanam akan Abū Bakr raḍiallāhu 'anhū pada belakang Rasulullah șallā allāh 'alaihi wa-sallam, dan ditanam akan 'Umar ibn al-Khaț̣̄āb radiallāhu 'anhū pada belakang dua kaki Abī Bakr ... (fol. 19v)

As related by 'Urwa ibn al-Zubayr: The Messenger of God was buried in an open space (tempatyang lapan $[g]$ ), and Abū Bakr was buried behind the Messenger of God, and 'Umar ibn al-Khațtāb was buried behind the two feet of Abī Bakr ...

Even though in the Daläil this section on the tombs is relatively short, it gave an opportunity for copyists to add illustrations to accompany the text. In this first type of visual representation, the three tombs are laid out in a diagonal line, reminiscent of steps rising from left to right.

Illustrations of the tombs in Southeast Asian Daläil manuscripts often incorporate local decorative motifs and elements, as can be seen in Ms Kuala Lumpur, Perpustakaan Negara Malaysia, Mss 4780, a manuscript from Aceh, dated $1181 / 1767 .{ }^{72}$ The manuscript contains illumination in the Acehnese style, consisting of a double-frame and several headpieces and tailpieces, all painted in red, dark blue, dark yellow, and "reserved white". ${ }^{73}$ A single-page illustration of the tombs appears before the description of the rawda, painted using the same set of colours as the illumination (fol. 95v; Figure 8). The three tombs-which are rendered dark blue - are set within an arch surrounded by vegetal ornamentation and a plaited rope motif, a distinctive feature of Acehnese art. ${ }^{74}$

\footnotetext{
71 Witkam, “The Battle of the Images," 71.

72 Perpustakaan Negara Malaysia, Katalog Manuskrip Melayu. Koleksi Perpustakaan Negara Malaysia. Tambahan Kesepuluh (Kuala Lumpur: Perpustakaan Negara Malaysia, 2018), 2.

73 On the Acehnese style, see Annabel Teh Gallop, "An Acehnese Style of Manuscript Illumination," Archipel 68 (2004): 193-240.

74 Gallop, "An Acehnese Style," 198-20o.
} 


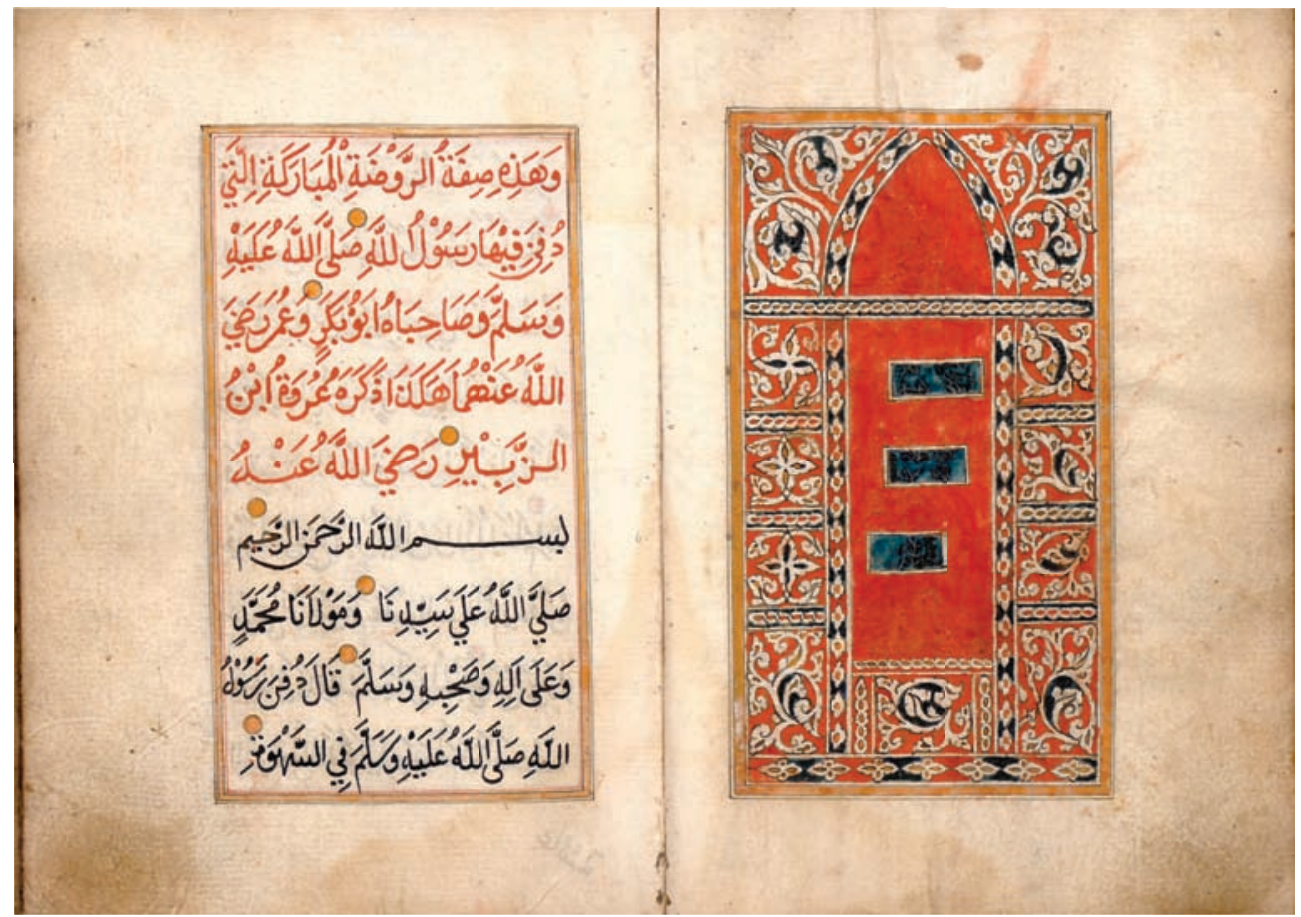

FIGURE $8 \quad$ Rawḍa. Al-Jazūlī, Dalä̉il al-khayrāt, Aceh, 1181/1767

MS KUALA LUMPUR, PERPUSTAKAAN NEGARA MALAYSiA, MSS 4780, FOLS. 95V-96r. COURTESY OF PERPUSTAKAAN NEGARA MALAYSIA

In MS Leiden, University Library Or. 7057a (6), probably dating to the eighteenth century, ${ }^{75}$ the illustration of the tombs is positioned in the middle of their description in the text (fol. 32v; Figure 9). Each tomb is depicted with a headstone and painted gold, with a caption identifying the person buried there. They are set within a golden building with a flared pyramidal roof. This representation reflects Southeast Asian architectural styles-local mosques, as well as pavilions erected over the graves of holy persons, often have this roof shape. ${ }^{76}$ The manuscript unfortunately is incomplete and does not mention a place or date of production, but similar images of the rawda can be found in Daläil manuscripts from the sultanate of Banten in West Java.

75 Witkam, Inventory of the Oriental Manuscripts, vol. 8, under Or. 7057a (6); Witkam, Vroomheid, 142; Witkam, "The Battle of the Images," 77.

76 For Southeast Asian mosque architecture, see Hugh O'Neill, "South-East Asia," in The Mosque: History, Architectural Development \& Regional Diversity, ed. Martin Frishman and Hasan-Uddin Khan (Cairo: American University in Cairo Press, 2002), 224-240. 


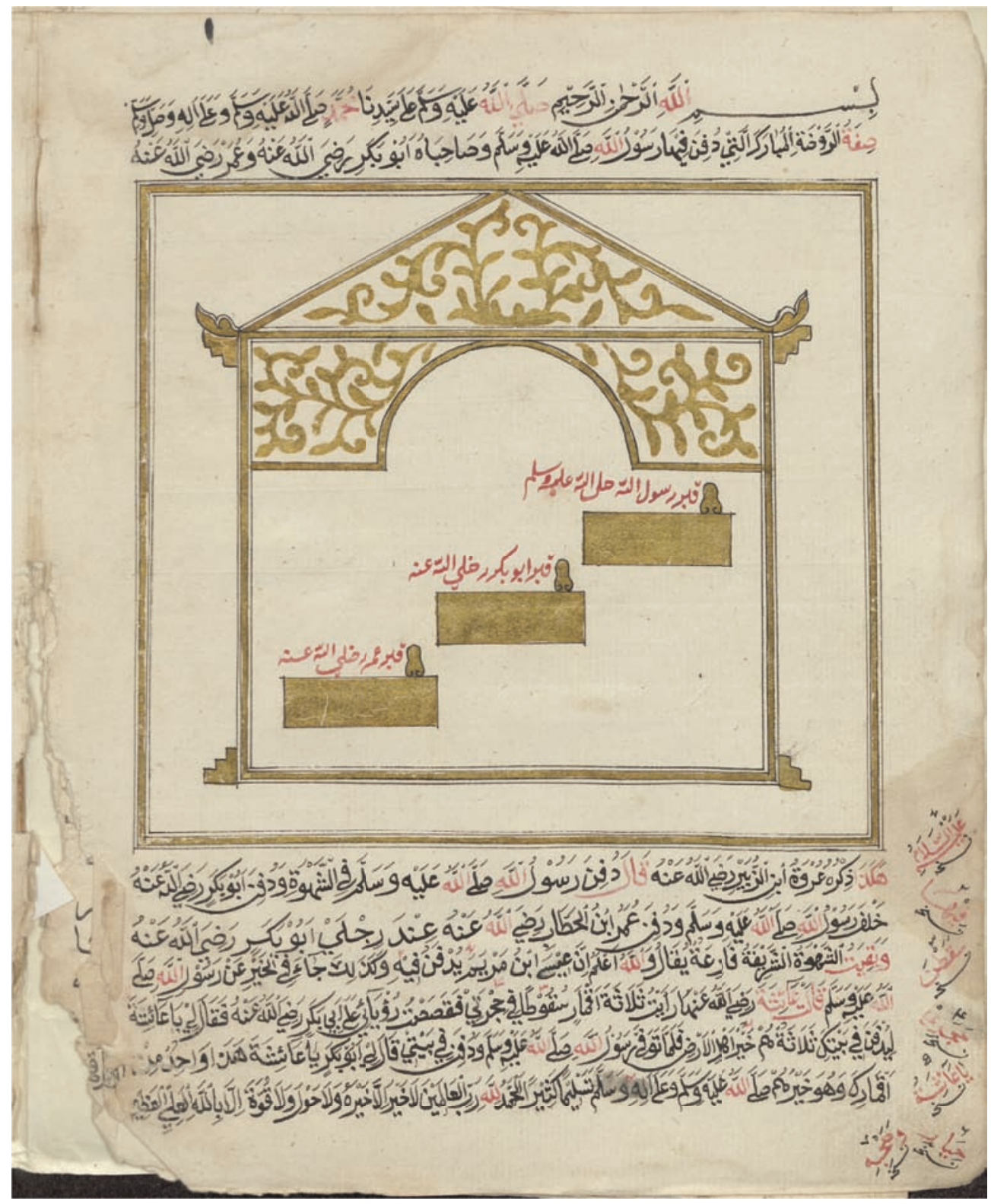

FIGURE 9 Raw ḍa. Al-Jazūlī, Dalāil al-khayrāt, Banten, eighteenth century MS LEIDEN, UNIVERSITY LIBRARY, OR. 7057A (6), FOL. 32V 


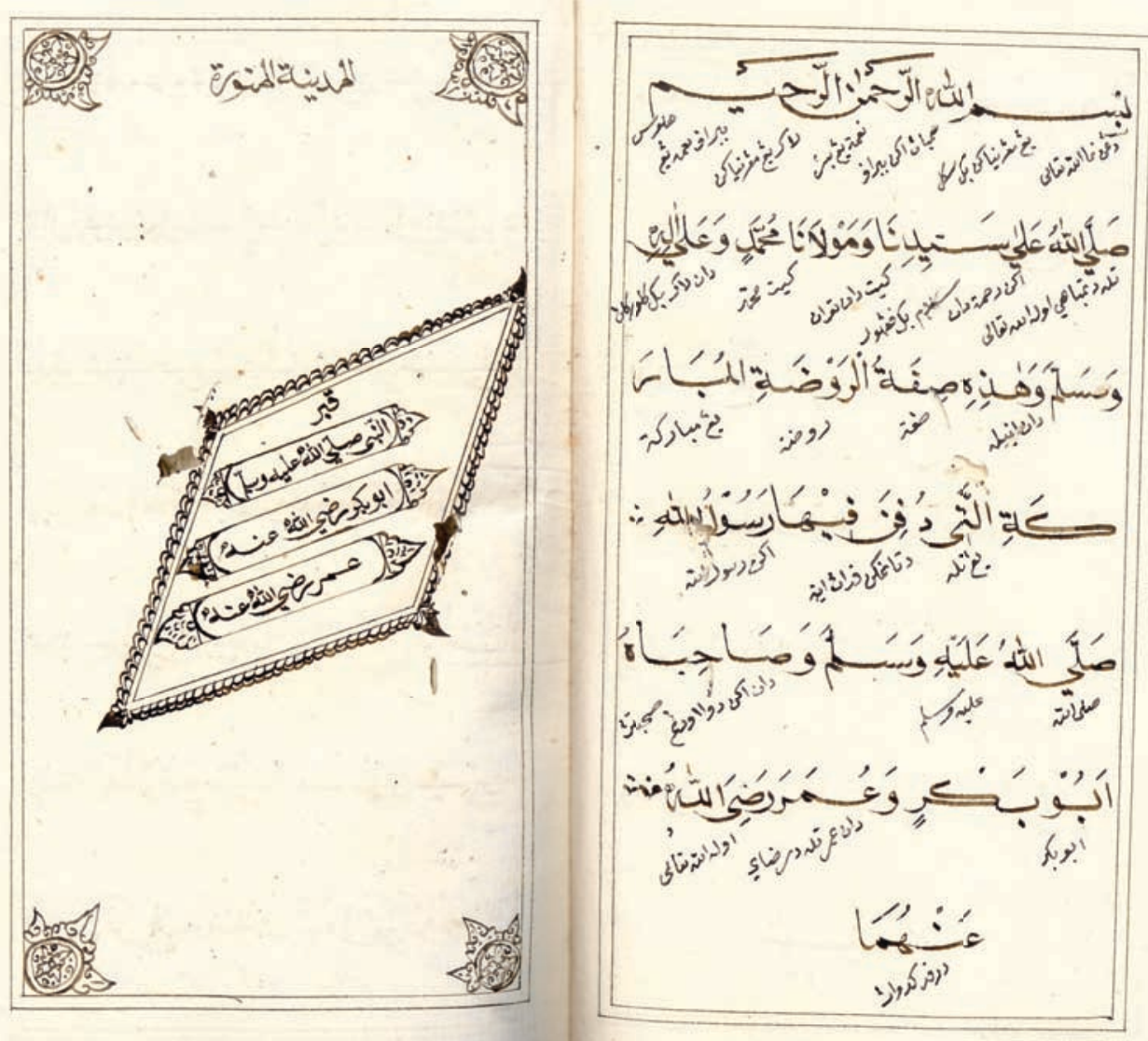

FIGURE 10 Rawḍa. Al-Jazūlī, Dalāil al-khayrāt, Singapore, 1298/1881

MS KUALA LUMPUR, PERPUSTAKAAN NEGARA MALAYSIA, MSS 2368, FOLS. 18V-19R. COURTESY OF PERPUSTAKAAN NEGARA MALAYSIA

Four of these are now held in Jakarta, in the Perpustakaan Nasional Republik Indonesia, A. $78-$ A. 81 , acquired from the Banten Royal Library in 1835.77 The images they contain are similar to Ms Leiden, University Library, Or. 7057a (6), with the tombs placed within a roofed pavilion (although not ornamented like they are in the Leiden manuscript), and painted in gold. The large size of the manuscripts (A. 78 measures $47.5 \times 32 \mathrm{~cm}$; A. 79 measures $53 \times 38 \mathrm{~cm}$ ), lack of frames around the text block, and minimal margins are features that they share in common with Qur'ans from the area. ${ }^{78}$ The illustration style and codi-

\footnotetext{
77 Annabel Teh Gallop and Ali Akbar, "The Art of the Qur'an in Banten: Calligraphy and Illumination," Archipel 72 (2006): 95-156: 99 and 103, fig. 6.

78 Gallop and Akbar, “The Art of the Qur'an in Banten," 99, 132.
} 


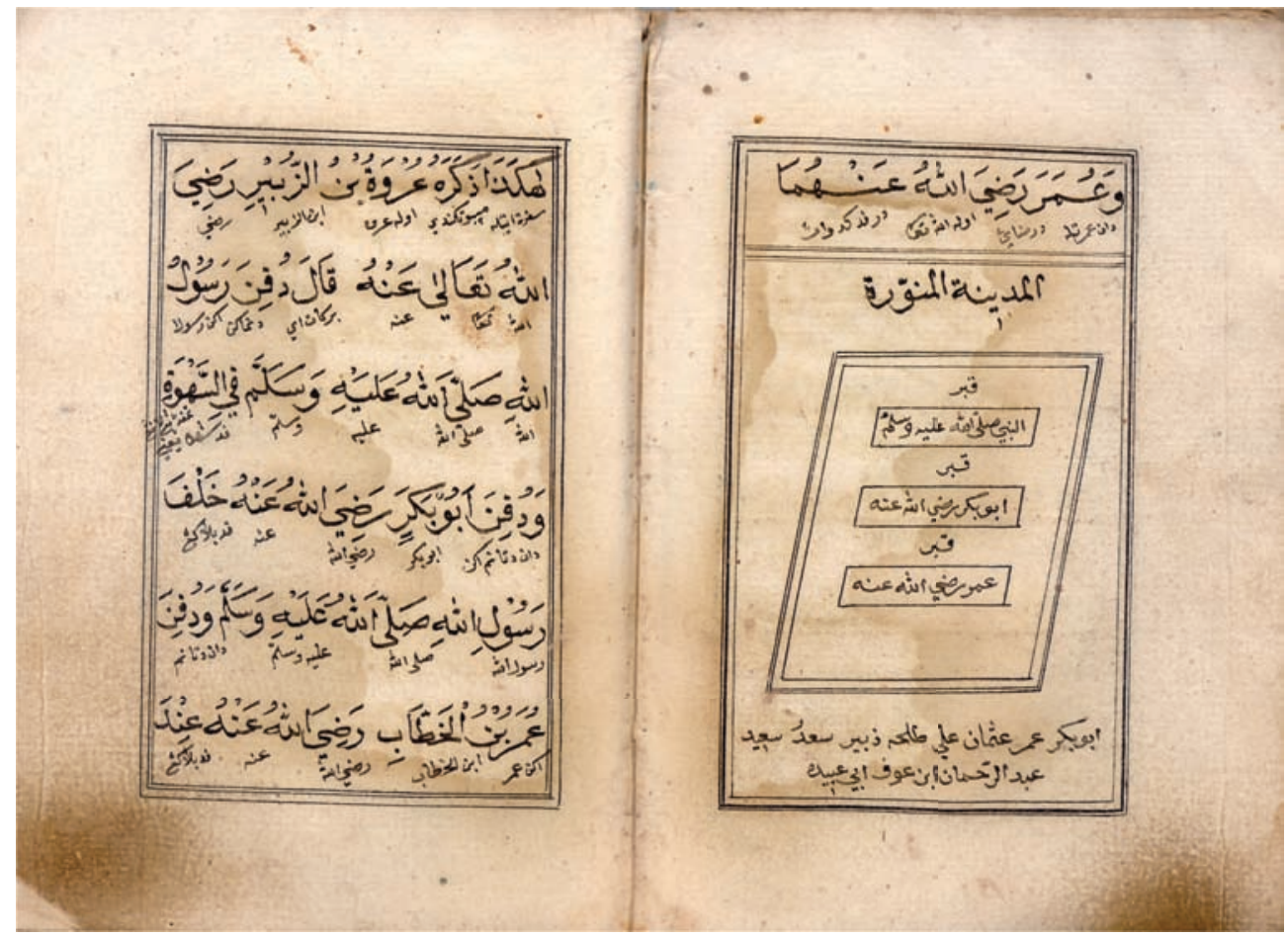

Figure 11 Rawḍa. Al-Jazūlī, Dalāil al-khayrāt, Jeruju Besar, 1310/1892

MS KUALA LUMPUR, PERPUSTAKAAN NEGARA MALAYSIA, MSS 3793, FOLS. 31V-32R. COURTESY OF PERPUSTAKAAN NEGARA MALAYSIA

cological aspects of these manuscripts point to the existence of a "Banten style", which could help us to identify the place of production for copies that lack detailed information, such as the Leiden manuscript above.

Nevertheless, manuscripts that share the same artistic style need not necessarily have been produced in the same place. For instance, as discussed above, Ms Kuala Lumpur, Perpustakaan Negara Malaysia, MSs 2368 (Singapore, 1811) and Ms Kuala Lumpur, Perpustakaan Negara Malaysia, Mss 3793 (Jeruju Besar, 1892), share the same interlinear Malay translation. They also have similar single-page illustrations of the rawda, placed in the middle of the text describing it (fol. 19r; Figure 10; and fol. 31v; Figure 11, respectively). In both cases, the tombs are laid out in a diagonal line, framed by a parallelogram. The illustrations are not painted (although the one in ms Kuala Lumpur, Perpustakaan Negara Malaysia, MSS 2368 does have some illumination), with captions written inside the tombs. The similarities between the two manuscripts indicate that they belong to the same textual and illustrated tradition, and they are both connected to the al-Idrus family. Yet, while ms Kuala Lumpur, Perpustakaan Negara 
Malaysia, MSS 2368 was copied in Singapore, internal evidence points to MS Kuala Lumpur, Perpustakaan Negara Malaysia, MSs 3793 being from western Borneo. It is unclear if the latter was copied directly from the former or from an intermediary source, but they demonstrate the presence of regional networks that facilitated the circulation of the texts and images of the Daläil.

\section{Double-Page Illustrations of the Tombs and the Pulpit of the Prophet}

The second type of visual representation features a double-paged illustration showing two aspects of the Mosque of the Prophet in Medina. Typically, the right page depicts the tombs of the Prophet Muhammad, Abū Bakr and 'Umar, shown in a similar way to the previously mentioned single-page illustration of the rawda. The opposite page shows the Prophet's minbar (pulpit) in the Mosque of the Prophet, usually a side view in the form of a right-angled triangle. Frequently, both are embellished with architectural elements, typically lamps hanging in an arch, placing them within the context of a mosque.

The earliest dated Southeast Asian Daläil - the aforementioned manuscript, now Ms Leiden, University Library, Or. 10.806, probably from Sumatra, dated 1143/1730-is of this type (fols. 33v-34r; Figure 1). The three tombs on the right-hand page are painted red. The minbar on the opposite page is depicted as a series of stepped boxes with an arch in front of it, reminiscent of those found in Moroccan manuscripts. ${ }^{79}$ This suggests that Southeast Asian practitioners during the eighteenth century had some access to illustrated copies of the Dalāil from Morocco, probably during their studies in Mecca and Medina. The images are accompanied by captions in Arabic, written upside down.

This type of double-paged composition continued into the nineteenth century. A manuscript in the Perpustakaan Negara Malaysia (MSS 1273), does not have a colophon, but it can be attributed to the region of Patani in Southern Thailand based on its illumination. ${ }^{80}$ The beginning of the recitations for the first Monday (fols. 19v-2or) is marked by an illuminated double page of the

79 See for instance the examples in Rusli, Daläil al-Khayrat, 113-119, figs. 6o-64. Hiba Abid, "Material Images and Mental Ziyāra: Depicting the Prophet's Grave in North African Devotional books (Dalāil al-Khayrat)," Journal of Material Cultures in the Muslim World 1(2020): 331--354.

8o Gallop, "The Spirit of Langkasuka?," 180-181, plates 38, 40; Farouk Yahya, "A Dalāil AlKhayrāt Manuscript”; Venetia Porter, The Art of Hajj (London: British Museum Press, 2012), 84-85, fig. 51 . 


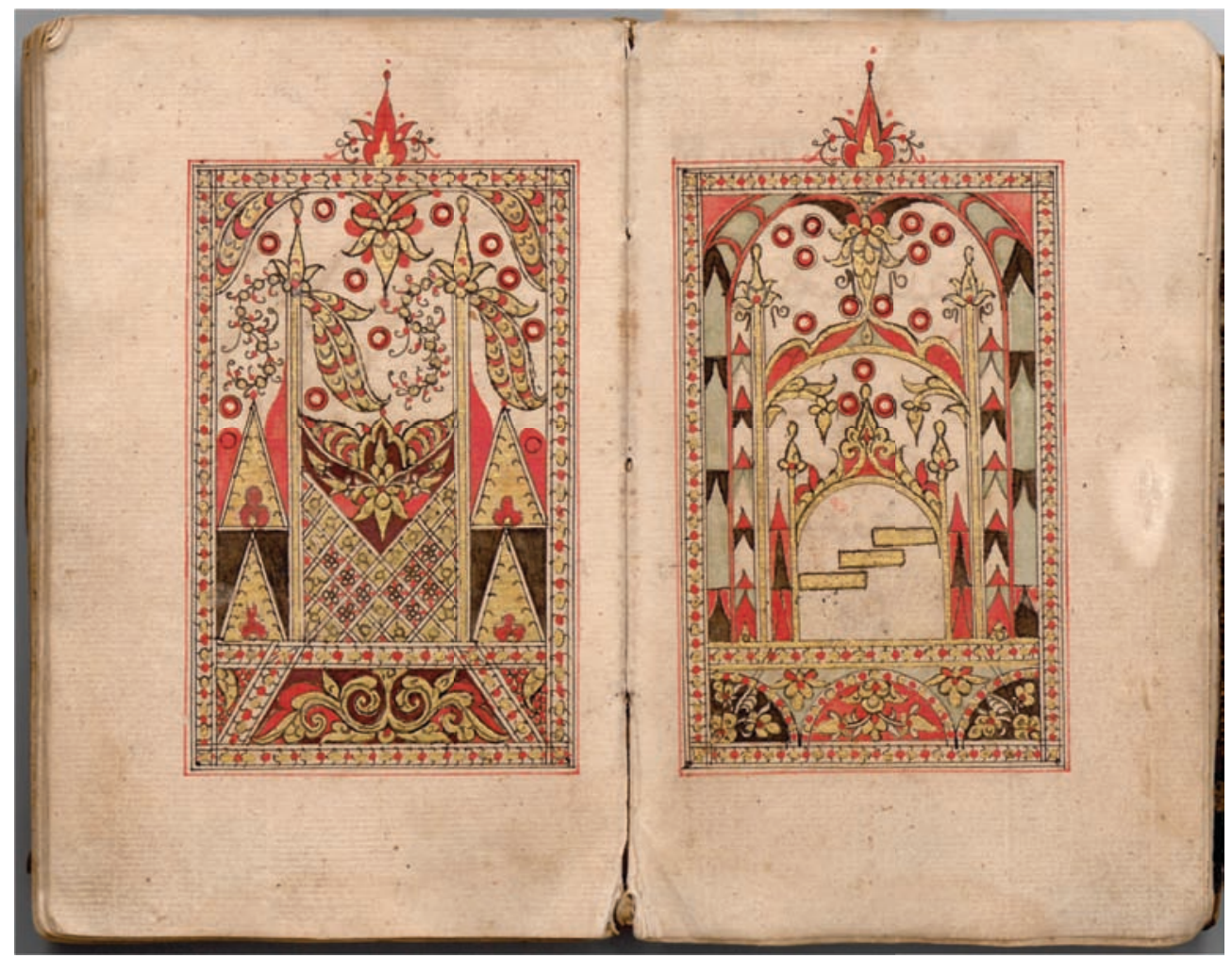

FIGURE 12A Raw MS KUALA LUMPUR, PERPUSTAKAAN NEGARA MALAYSIA, MSS 1273, FOLS. 14V-15R. COURTESY OF PERPUSTAKAAN NEGARA MALAYSIA

Patani style, with a colour palette of gold, red, "reserved white", and a dark shade of greyish green. ${ }^{81}$

The manuscript also contains a double-page illustration of the rawda and the pulpit, set within a pair of near-identical frames (fols. 14v-15r; Figure 12a). The three tombs are painted gold and placed under a series of arches that culminate in a golden lamp at the top. On the opposite page, the pulpit is sandwiched between triangular shapes on each side, with an arch above it from which hangs a golden lamp. At the bottom of both pages are rectangular panels filled with vegetal and floral designs.

Typically, the pulpit is shown as a triangle in copies of the Daläil. Here, however, it is made up of two triangles joined in the middle, with a tall pole on each

81 See Gallop, "Seni Hias Manuskrip Melayu," 256, fig. 165. 


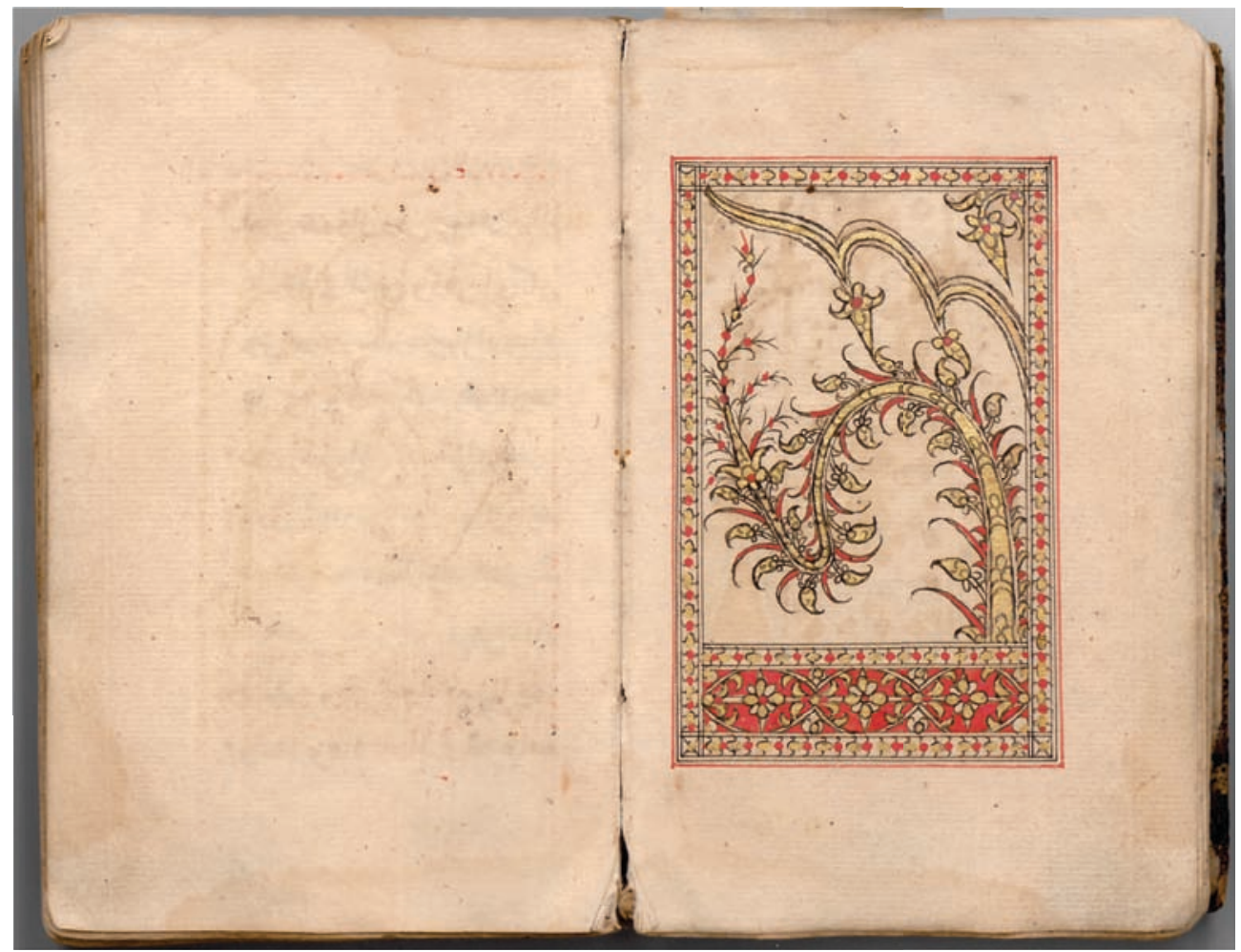

FIGURE 12B Unidentified object, perhaps a tree in Paradise. Al-Jazūlī, Dalāil al-khayrāt, probably Patani, nineteenth century MS KUALA LUMPUR, PERPUSTAKAAN NEGARA MALAYSIA, MSS 1273, FOLS. 15V-16R. COURTESY OF PERPUSTAKAAN NEGARA MALAYSIA

vertical side. A pair of flags are attached to the tops of the poles. This reflects the Southeast Asian practice of placing flags on each side of a pulpit ${ }^{82}$ and, as a result, the pulpit now appears to have been given a frontal view.

The lamps above are shaped as lotus flowers drawn in profile. The lotus motif, a Hindu-Buddhist symbol of purity and beauty, is common in Southeast Asian art, and this particular design can be seen in Malay manuscript illumination as well as woodwork and metalwork. ${ }^{83}$ Similarly, the foliage motif in the

82 For instance, see the minbar of Masjid Pasir Pekan in Kelantan, formerly in Masjid Kampung Laut (also in Kelantan), in Abdul Halim Nasir, Ukiran Kayu Melayu Tradisi (Kuala Lumpur: Dewan Bahasa dan Pustaka, 1986), 22; also the minbar of Masjid Wapaue in Ambon in O’Neill, “South-East Asia," 230.

83 Farouk Yahya, "A Dalāil Al-Khayrāt Manuscript," 33; Farouk Yahya, Magic and Divination, 214. For examples on woodwork, see the early-twentieth-century biscuit moulds from 
rectangular panel underneath the pulpit could also be found in other media such as woodwork, demonstrating a shared artistic vocabulary. ${ }^{84}$

On the page following the pulpit is an illustration of a long, wavy object resembling a frond, coloured in gold, with red tendrils and little gold "chillies" emanating from its body (fols. 15v-16r; Figure 12b). Above it are three lotus flower motifs similar to the lamps. The meaning of this composition has yet to be determined. It might have a symbolic or talismanic significance. ${ }^{85}$ Another possibility is that it denotes a tree in Paradise, like the Sidrat al-Muntahā or the Tūba a . The Sidrat al-Muntahā is illustrated in the Imam Bonjol manuscript (Ms Leiden, University Library, Or. 1751, p. 125), while a mawlid manuscript from the Philippines (Ms Marawi City, Dansalan College, Gowing Memorial Research Centre, MF242.7 T19 V1-2) contains a depiction of a tree which might represent the T⿱üba ${ }^{86}$

\section{Double-Page Illustrations of Mecca and Medina}

In the third type of representation, the Daläil manuscripts contain a pair of illustrations with Mecca on one page (usually the right), and Medina on the opposite page. Mecca is represented by the Masjid al-Ḥarām, identifiable by the black cube of the Ka'ba at its centre. As for Medina, the three tombs and the pulpit are now depicted together within the compound of the Mosque of the Prophet. ${ }^{87}$

Patani and Kelantan in Farish A. Noor, Eddin Khoo and David Lok, Spirit of Wood:The Art of Malay Woodcarving: Works by Master Carvers from Kelantan, Terengganu and Patani (Singapore: Periplus, 2003), 92-94. On the lotus motif in Malay art, see Ivor H.N. Evans, "Some Malay Patterns and Designs," Journal of the Federated Malay States Museum 12 (1924-1929), $163^{-167}$, figs. $\mathrm{i}-\mathrm{X}$.

84 A similar design appears, for example, on a wood panel in the eighteenth-century Masjid Aur Menatjung, Patani; see Farish, Khoo and Lok, Spirit of Wood, 73.

85 There is a similar drawing in an Ottoman prayer book in Ms Ankara, Ethnography Museum, Inv. no. 17069, fol. 122a, which depicts a number of curving fronds. It might be a talismanic design. Many thanks to Sabiha Göloğlu for sharing images of this manuscript with me.

86 For the mawlid manuscript, see Annabel Teh Gallop, "Islamic Manuscript Art of the Philippines," in The Qur'an and Islamic Manuscripts of Mindanao, ed. Kawashima Midori (Tokyo: Institute of Asian Cultures, Sophia University, 2012), 71-105, esp. 83-84 and fig. 34.

87 For the structures depicted within the two sanctuaries, see Rusli, Daläil al-Khayrat, ${ }_{128}$ 133; see also Beyazit, "Defining Ottoman Realism," 223-229. For a discussion on the Ka'ba, see Simon O'Meara, The Ka'ba Orientations: Readings in Islam's Ancient House (Edinburgh: Edinburgh University Press, 2020), 119-122. 
In Southeast Asian copies, these views are represented schematically, with the compound of the two mosques being shown in flat projection (from the top), but the structures they contain are in elevation view (from the side) and not true to scale. They are similar to Daläil manuscripts from other parts of the Islamic world that belong to an earlier Ottoman visual tradition of depicting the holy cities, which are not meant to be realistic representations but instead "allow the viewer to visualise and evoke these places in his or her mind's eye." 88

Ms Kuala Lumpur, Perpustakaan Negara Malaysia, MSs 1740, from Java, dated $1188 / 1774$, is of this type. ${ }^{89}$ It contains a double-page illustration depicting the two holy sanctuaries, with the structures within them highlighted in gold and given captions in Arabic (fols. 15v-16r; Figure 13). In the depiction of Medina, the three tombs are laid out in the top left-hand corner within a green rectangular structure, with the pulpit set in the space on its right. At the bottom of the page are palm trees denoting the garden of Fātima. This is the earliest known Southeast Asian example of this type of composition, indicating that it was in place within the region by the second half of the eighteenth century.

A number of Southeast Asian manuscripts, including this Javanese copy, show some similarities with manuscripts of the Daläil from South Asia, particularly Kashmir. This can be seen in features such as the compartmentalization of the three tombs in Medina within a rectangular structure on the upper lefthand corner of the page (Figure 14). ${ }^{90}$ Additionally, some Indian and Ottoman copies fill the entire surface of the two pages with profuse ornamental motifs. ${ }^{91}$

88 David J. Roxburgh, "Visualizing the Sites and Monuments of Islamic Pilgrimage," in Architecture in Islamic Arts: Treasures of the Aga Khan Museum, ed. Margaret S. Graves and Benoît Junod (Geneva: Aga Khan Trust for Culture, 2011), 33-40: 38; Margaret S. Graves, "Double-Page Composition Showing Mecca and Medina," in Graves and Junod, Architecture in Islamic Arts, 44-45, cat. 2, where the quote was taken from. For a synthesis on various functions and meanings of this imagery, with detailed bibliography, see Beyazit, "Defining Ottoman Realism," especially 209 and 233; see also Göloğlu, "Depicting the Islamic Holy Sites."

89 Perpustakaan Negara Malaysia, Manuskrip Melayu Koleksi Perpustakaan Negara Malaysia. Satu Katalog Ringkas. Tambahan Ketiga (Kuala Lumpur: Perpustakaan Negara Malaysia, 1997), 22. It is made of dluwang (bark cloth), which points to its origins in Java where this material was used.

9o The compartmentalization of key structures within the painting composition is a characteristic of the Kashmiri style; see Rusli, Dalä'il al-Khayrat, 133, caption to fig. 82, with further examples on 139-141, figs. 89-91. See also the Kashmiri copy in Toronto, (MS Toronto, Aga Khan Museum, AKM 278); see Deniz Beyazit, "Dala'il al-Khayrat Prayer Book," Aga Khan Museum, https://www.agakhanmuseum.org/collection/artifact/dalail-al -khayrat-prayer-book-akm278.

91 See for instance the examples in Graves, "Double-Page Composition;" Rusli, Dalāil alKhayrat, 134-135, fig. 85 . 


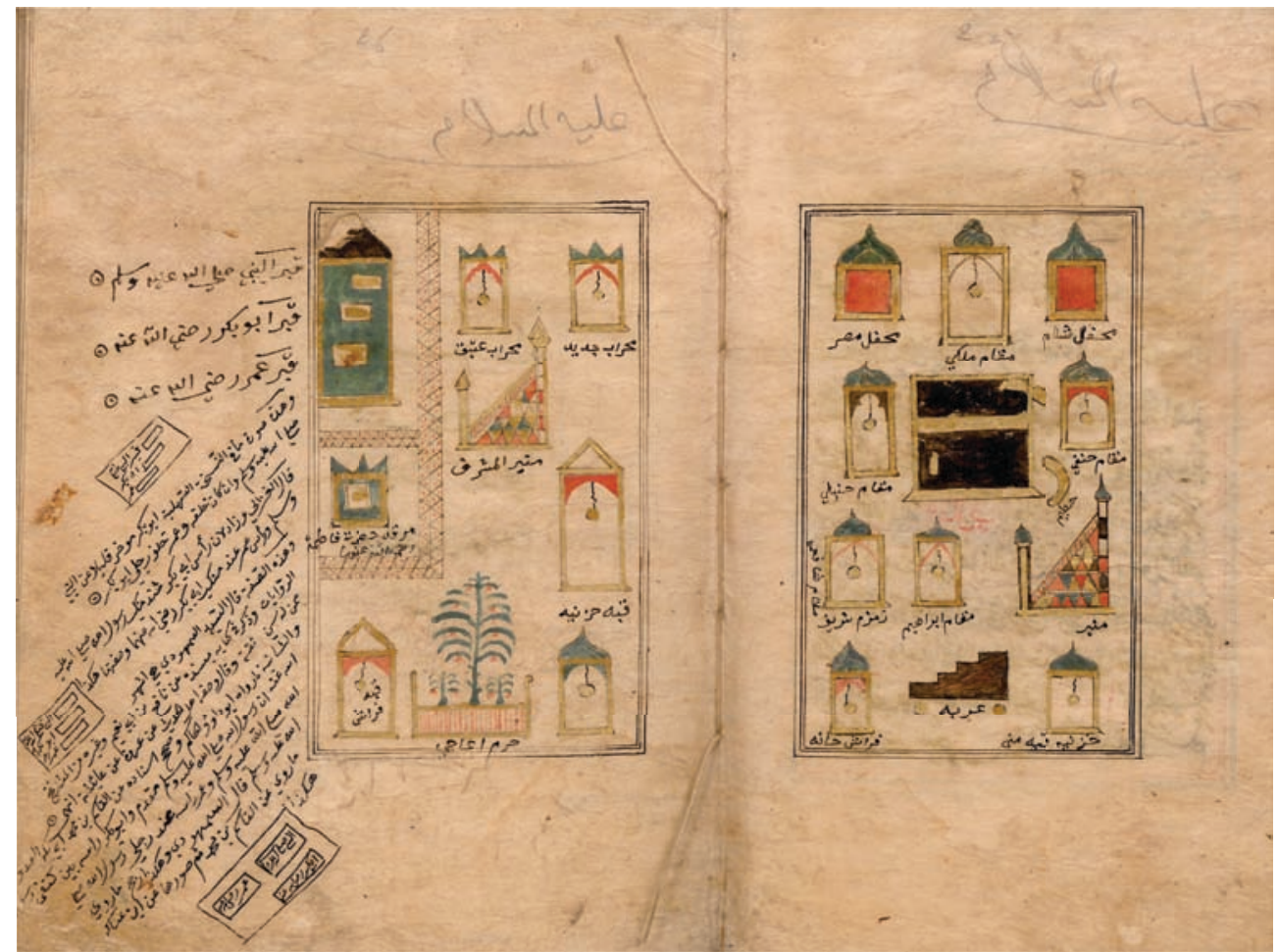

FIgURE 13 Mecca and Medina. Al-Jazūlī, Dalā̇il al-khayrāt, Java, 1188/1774. In the margin of fol. 16r are notes on the relative positions of the three tombs

MS KUALA LUMPUR, PERPUSTAKAAN NEGARA MALAYSIA, MSS 1740, FOLS. 15V-16R.

COURTESY OF PERPUSTAKAAN NEGARA MALAYSIA

Such copies may have provided the inspiration for certain Southeast Asian manuscripts such as one from Terengganu, dateable to the nineteenth century (MS Singapore, Asian Civilisations Museum Inv. No. 2007-53427). ${ }^{92}$ Here, every available space in the images of Mecca and Medina has been filled with intricate gold foliate designs (Figure 15). Nevertheless, there are notable differences between the Kashmiri and Southeast Asian paintings. They each have different colour palettes (for instance, pink is often used in Kashmiri examples, but not in Southeast Asia), and Kashmiri manuscripts often depict onion domes surrounding the perimeters of the mosques of Mecca and Medina, but these are rarely found in Southeast Asian examples.

92 National Heritage Board, "Guide to Goodness (Dalail al-Khayrat)," Roots, https://www .roots.gov.sg/Collection-Landing/listing/1031226. 


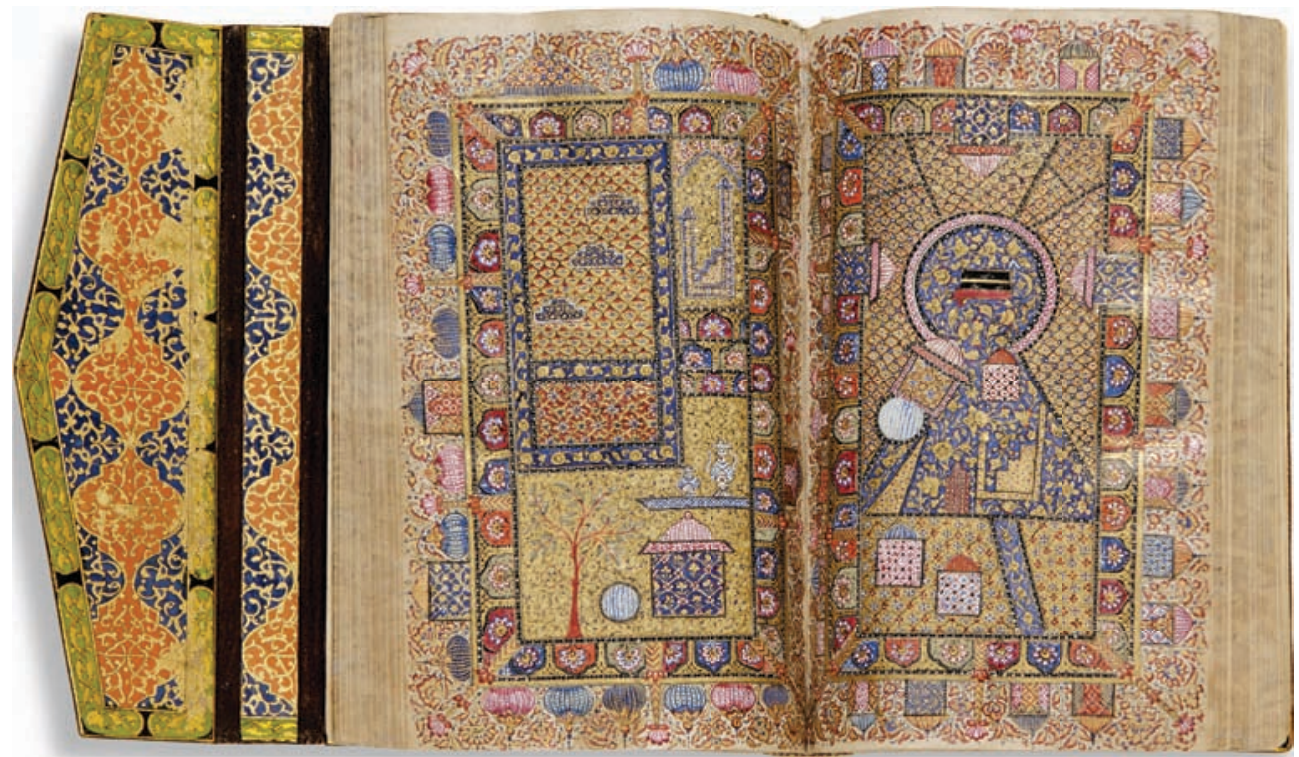

FIGURE 14 Mecca and Medina. Al-Jazūlī, Dalā'il al-khayrāt, probably Kashmir, 1233/1818 MS TORONTO, AGA KHAN MUSEUM, AKM 278, FOLS. 11OV-111R. (C) THE AGA KHAN MUSEUM

The onion domes, however, are found in a nineteenth-century copy of the kitab maulid ("book on the nativity [of the Prophet]"), probably from Patani, now Ms Kuala Lumpur, Perpustakaan Negara Malaysia, Mss 2940. ${ }^{93}$ Like the Dalä’il, mawlid texts were also recited communally, with the Sharaf al-ānām ("Honour of Humankind"), and the mawlid written by Jafar al-Barzanjī (d. c. 1177/1764) being among the most popular in Southeast Asia. ${ }^{94}$ Their manuscripts are often illuminated, but this copy is the only known example to have a paired representation of Mecca and Medina (images of the two holy sites also appear in the opening pages of a printed edition published by Menara Kudus in Java, ca. 1995). ${ }^{95}$

Occasionally, one finds the order of the images reversed, such as in a Daläil copied by a Bugis scribe from Wajo, South Sulawesi, dated 1284/1868 (MS New York, New York Public Library, Arabic Ms. No. 256). ${ }^{96}$ Here, the image of Mecca

93 See Gallop, "The Spirit of Langkasuka?," 180, plate 39.

94 On the mawlid texts and celebrations, see Katz, The Birth of the Prophet Muhammad.

95 See Witkam, Vroomheid, 105.

96 Barbara Schmitz, Islamic Manuscripts in the New York Public Library (New York: Oxford University Press, 1992), 48. Many thanks to Hiba Abid for informing me about this manuscript. The name of the scribe is 'Abd Allah al-Buqisi al-Waj (fol. 152v). 


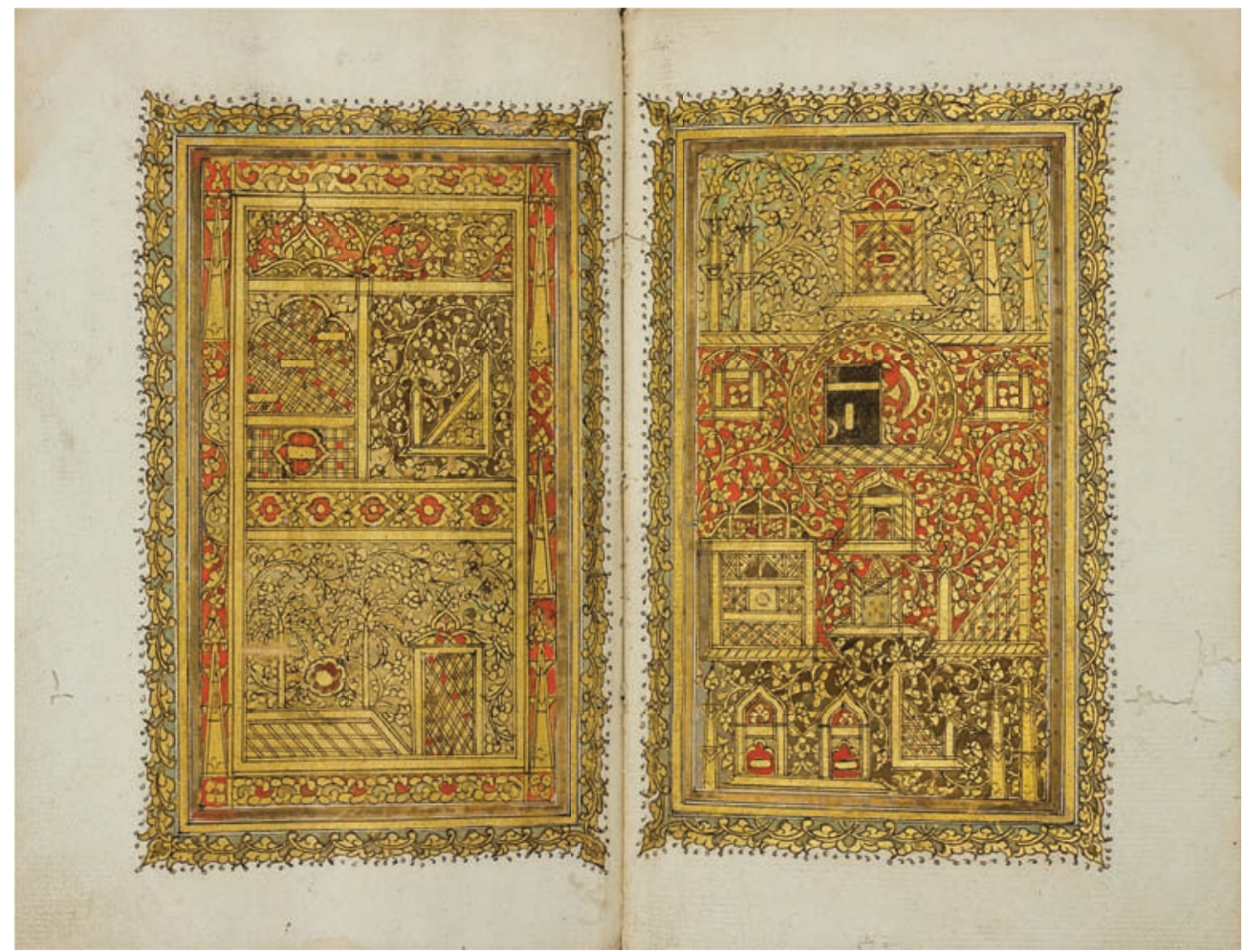

FIGURE 15 Mecca and Medina. Al-Jazūlī, Dalā̉il al-khayrāt, Terengganu, nineteenth century MS SINGAPORE, ASIAN CIVILISATIONS MUSEUM, INV. NO. 2007-53427. COURTESY OF ASIAN CIVILISATIONS MUSEUM

has been placed on the left-hand page, while that of Medina is on the right (fols. 23v-24r; Figure 16). Similar arrangements can also be found in Daläil manuscripts from India. ${ }^{97}$

In a Daläil manuscript probably from Patani, southern Thailand, dated 1233/1818 (now Ms Kuala Lumpur, Perpustakaan Negara Malaysia, MSs 1974), the double page illustration similarly depicts Mecca on the left, but the righthand page depicts only the rawda, without the minbar (fols. 2v-3r). This rawdaMecca combination could also be found in a Quran from Aceh dateable to the nineteenth century (MS Kuala Lumpur, Perpustakaan Negara Malaysia, MSS 4777 , fols. 1v-2r), although here Mecca is placed on the right, while the rawda is on the left. ${ }^{98}$

97 See for instance the examples in Porter, The Art of Hajj, 82-83, fig. 50; Rusli, Daläil alKhayrat, 138, fig. 88.

98 Annabel Teh Gallop, "Qur’an Manuscripts from Mindanao: Collecting Histories, Art and 

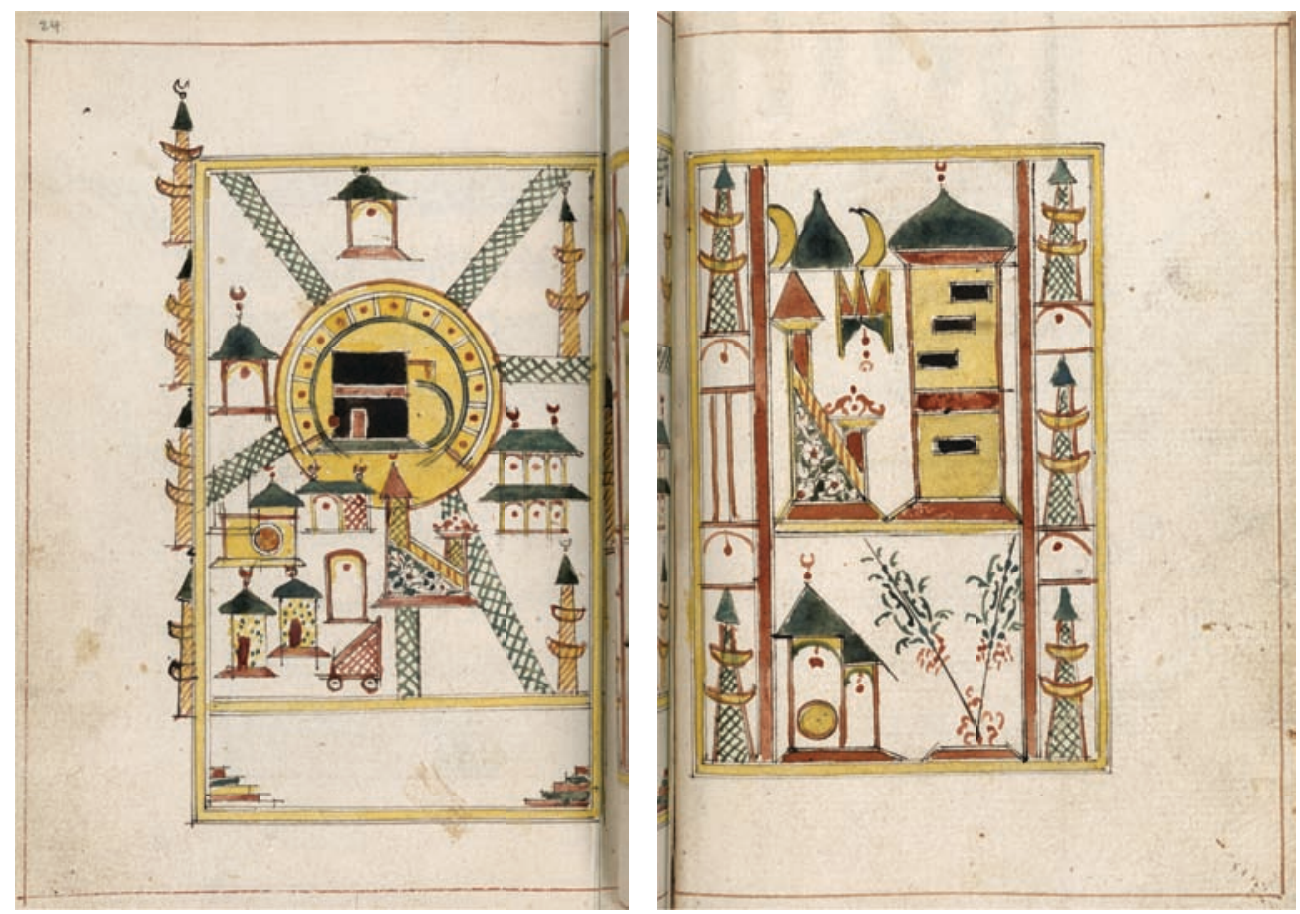

FIGURE 16 Medina and Mecca in reverse order. Al-Jazūlī, Dalāill al-khayrāt, probably Wajo, South Sulawesi, $1284 / 1868$

MS NEW YORK, THE NEW YORK PUBLIC LIBRARY, ARABIC MS. NO. 256, FOLS. 23V-24R (ARABIC MANUSCRIPTS COLLECTION. MANUSCRIPTS AND ARCHIVES DIVISION. THE NEW YORK PUBLIC LIBRARY. ASTOR, LENOX, AND TILDEN FOUNDATIONS)

Similarly, the minbar is not visible within the Mosque of the Prophet in a Daläil manuscript from Palembang, dateable to 1804-1843 (Ms Leipzig, University Library, Gabelentz 52 , fols. $15 \mathrm{v}-16 \mathrm{r}$ ). Unusually, only two tombs are depicted in the mosque instead of the usual three (each housed within their own separate structures). ${ }^{99} \mathrm{~A}$ depiction of two graves (housed within one building) can also be found in a Qur'an from Mindanao, southern Philippines. ${ }^{100}$ While illus-

Materiality," South East Asia Research 2021 DoI: 10.1080/o967828X.2021.1895674, 19. For images of the manuscript, see the Facebook page of the Pusat Kebangsaan Manuskrip Melayu of the Perpustakaan Negara Malaysia, post-dated 2 July 2015, https://www.face book.com/permalink.php?story_fbid=837274883021845\&id=597459577003378.

99 See Wiesmüller, "Von Istanbul nach Palembang," fig. 2. I am grateful to Annabel Teh Gallop for bringing this to my attention.

100 Gallop, “Qur’an Manuscripts from Mindanao," 19 and fig. 16. 
trations of the Mosque of Medina may depict four tombs (Muhammad, Abū Bakr, 'Umar and Fātima; see Figs. 13, 15, 16), the meaning behind this iconography of two tombs is unclear.

In some cases, the forms of the structures depicted in the paintings are based on local Southeast Asian architecture, as noted in the Banten manuscript above (Figure 9). A further example is the aforementioned Syed Muhammad al-Idrus manuscript from Terengganu, dated 1250/1835, Ms Kuala Lumpur, Islamic Arts Museum Malaysia, 1998.1.2607. The entire composition depicting Mecca and Medina is painted in gold, except for the Kaba, which is black (pp. 10-11).101 The Mosque of the Prophet in Medina is shown with a double-tiered flared roof with curved ridges, topped by an ornamental finial. Images of similar buildings appear in manuscript painting from the region. ${ }^{102}$ Their designs are based on Southeast Asian mosque architecture. ${ }^{103}$

\section{Printed Editions of the Dalā'il}

Copies of the Daläil were also published in printed form. During the nineteenth and early twentieth centuries, books for the Southeast Asian market were also being printed in Bombay, including an edition of the Daläil published in $1877 \cdot{ }^{104}$

Printed editions of the Daläil are still circulating in Southeast Asia. ${ }^{105}$ A copy, now in the library of Sophia University in Tokyo (167.6:D32:K), was acquired in a bookstore in Surabaya, Java in $2007 .{ }^{106}$ It was published by alHaramayn, a publisher based in Singapore and Jeddah, although this edition (which is undated) is probably an Indonesian reprint. ${ }^{107}$ Several sections of the book are illuminated, and it also contains illustrations of Mecca and Medina,

\footnotetext{
101 See Barakat and Rusli, "The Royal Daläil al-Khayrāt", in the present volume.

102 Farouk Yahya, Magic and Divination, 194.

103 O'Neill, "South-East Asia."

104 Ian Proudfoot, "Malay Books Printed in Bombay: A Report on Sources for Historical Bibliography," Kekal Abadi 13, no. 3 (1994): 1-20: 17.

105 Witkam, Vroomheid, 212-217.

106 Kawashima Midori, ed., A Provisional Catalogue of Southeast Asian Kitabs of Sophia University (Second Version) (Tokyo: Institute of Asian Cultures-Center for Islamic Area Studies, Sophia University, 2015), 468, no. 1826. I am grateful to Kawashima Midori for her kind assistance with the Sophia University Library collection.

107 On this publisher, see Martin van Bruinessen, "Kitab Kuning: Books in Arabic Script Used in the Pesantren Milieu: Comments on a New Collection in the KITLV Library," Bijdragen tot de Taal-, Land- en Volkenkunde 146, no. 2/3 (199o): 226-269: 233.
} 


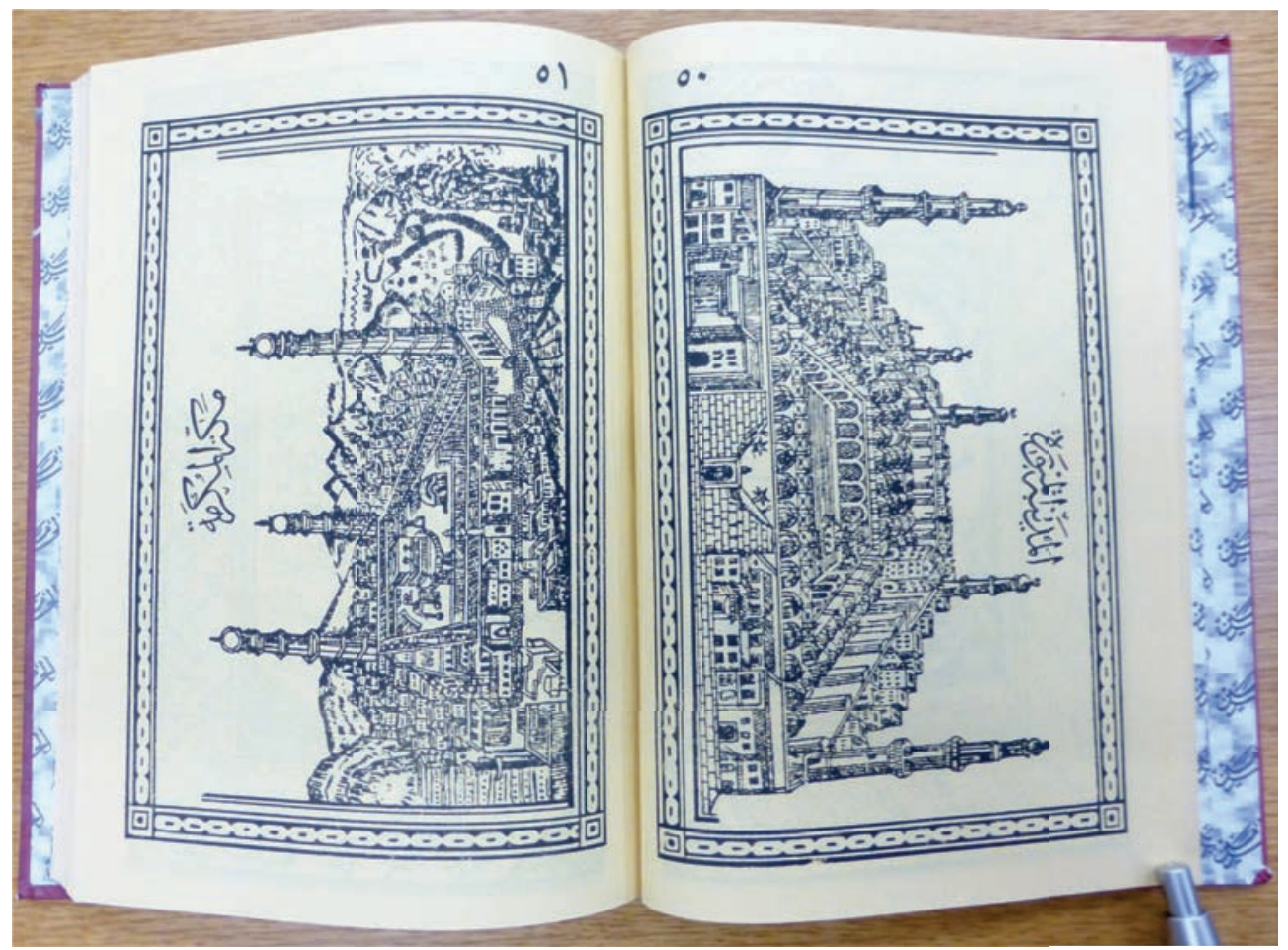

FIGURE 17 Mecca and Medina. Al-Jazūlī, Dalāil al-khayrāt, Singapore, Jeddah, Indonesia: al-Haramayn, [no date].

TOKYO, SOPHIA UNIVERSITY LIBRARY, 167.6:D32:K, PP. 50-51. PHOTO: FAROUK YAHYA

with Mecca placed on the left-hand page, and Medina on the right (pp. 50-51; Figure 17). The designs of the illustrations originated in Ottoman lithographical editions of the Daläil. ${ }^{108}$ The presence of illumination and illustrations here shows that printed books still continued the artistic convention found in manuscript copies of the Daläil.

There are also printed copies of the Malay translation of the Daläil. One, titled Petunjuk Cara Memperoleh Syafaat Nabi SAW ("Guidance on How to Obtain the Intercession of the Prophet") was published by Husaini Publishers in Bandung, Java, in 1997 and acquired by the author in Kuala Lumpur in 2006. ${ }^{109}$ Here, the Malay translation in Roman script is given after each section of the Arabic text, i.e. unlike the earlier manuscripts, the translations are not interlinear. The book does not contain any illustrations or illumination.

108 Similar images are found in an edition published in Istanbul in 1302/1885. See Witkam, Vroomheid, 202-209.

109 On this publication, see Witkam, Vroomheid, 211-213. 
Manuscripts of the Dalāil al-khayrāt from Southeast Asia are similar to those from other parts of the Islamic world, both in terms of textual content and the choice of images. Further studies on the texts, artistic styles, and individuals who produced and used the manuscripts could help in understanding the dissemination and usage of the Daläil in the region. Whether introduced and circulated through Sufi networks centred in Mecca and Medina, Moroccan and Ottoman manuscripts, or Hadhrami families residing in Southeast Asia, the Dalàil gained wide acceptance and gave rise to a variety of local practices. At the same time, the artistic styles of the manuscripts are often very much rooted in the Southeast Asian painting tradition.

The illustrations and illumination contained in the manuscripts also remind us that the Dalāil was not only meant to be read, but also to be seen. ${ }^{110}$ Further research into the function of the art could enhance our understanding of how the manuscripts were used. Illumination, for instance, serves to decorate the manuscript and to mark out important sections of the text. The function of illustrations, however, is perhaps more complex. Most importantly, they are a visual reminder to the reader of the Prophet Muhammad, who is the subject of the prayers, prior to commencing the recitation. They may also serve to elucidate the text, as with the image of the three tombs that accompanies their textual description. Witkam has argued, on the basis of a text of the Hadith, that the double-image of the tombs and pulpit enables the reader to "place" himself in between the two sacred sites and "to be in one of the gardens of Paradise", while, according to him, the double images of Mecca and Medina were possibly the result of a greater awareness to place God first and foremost instead of Muhammad, as a visual expression of the shahāda formula. ${ }^{111}$ Or perhaps, as Sabiha Göloğlu has suggested, it served as "visual propaganda" for the Ottomans, among its various other uses. ${ }^{112}$ Yet, the question is how much of these interpretations can be applied to the Southeast Asian context? Were the artists of the manuscripts aware of these underlying meanings, or did they

\footnotetext{
110 Cf. illuminated copies of the Qur'an; see Alain George, "Calligraphy, Colour and Light in the Blue Qur'an," Journal of Qur'anic Studies 11, no. 1, (2009): 75-125: 107.

111 Witkam, Vroomheid, 76-92; Witkam, "The Battle of the Images," 72-75. His hypothesis about the Medinan double image has since been confirmed by manuscripts in the Bibliothèque nationale de France. See Jan Just Witkam, 'Medina and Mecca revisited. Further thoughts on the illustrations in Dalāil al-Khayrāt by al-Ǧazūlī', in the present volume.

112 Göloğlu, "Depicting the Islamic Holy Sites," 327.
} 
merely follow the conventions laid out in previous copies? Or did the meanings of the images change? These are issues that still require further investigation.

Furthermore, we must consider how and where the manuscripts were read. The Daläil was often recited aloud in a collective manner, in which case the illuminated divisions are an aid to the recitation. As for the illustrations, presumably the section describing the tombs would not have been recited aloud (as far as the present author can determine). Nevertheless, if each person in the group had his own illustrated manuscript, then the religious imagery it contained, combined with the presence of other human beings, as well as the body movements (as in Aceh) and sounds (not only of the chanting but also music, as in West Sumatra), would have added to the sensorial experience of the reading, and possibly helped to provide spiritual encouragement to the reader with the recitation. The gold used for the illumination and illustrations in luxury copies, flickering in the candlelight when viewed during nighttime recitations, must have produced a dazzling effect.

These luxury copies also remind us that a manuscript is also an object in itself with a value that goes beyond its function. It may be that a beautifully illustrated copy of the Daläil was not only meant to be read, but also to be appreciated for its preciousness. ${ }^{113}$ Although the Qur'an usually receives the best and most lavish attention with regards to decoration, Southeast Asian manuscripts of the Dalä'il have revealed similarly high levels of beautification - both in terms of quantity and quality — a testament to the high regard placed upon this text by the people of the region.

\section{Acknowledgements}

This is a revised version of the papers presented at the workshop From West Africa to Southeast Asia: The History of Muhammad al-Jazuli's Dala'il al-Khayrat Prayer Book (15th-2oth Centuries) (Metropolitan Museum of Art, New York, 2019) and the Research Seminar in Islamic Art (ReSIA) (sOAs University of London, 2019) - many thanks are due to the organizers and attendees. I am grateful to the staff of the various collections for their assistance in facilitating my research and for their permission to reproduce the images. In addition, I would also like to thank the editors of this special issue of the Journal of Islamic Manuscripts, as well as Anna Contadini, Annabel Teh Gallop, Owen Wright and

113 Many thanks to Anna Contadini for this observation. 
others for their comments and assistance on various points of the article. Any mistakes are my own.

\section{A Appendix: Daläil al-khayrāt manuscripts from Southeast Asia}

This is a preliminary list of manuscripts of the Daläil al-khayrāt from Southeast Asia. It is not an exhaustive list and the author has not been able to personally consult all of them.

\section{A.1 France}

Bibliothèque nationale de France, Paris

- Mal-Pol 109: Indonesia or Malaysia, 1825. In a collective volume with other texts including on magic and divination.

\section{A.2 Germany}

Leipzig University Library

- Ms. Gabelentz 52: Palembang, c. 1804-1843. Owned by Sultan Mahmud Badaruddin II of Palembang (d. 1850). Illuminated; double-page illustration with Mecca on the right and Medina on the left (fols. $15 \mathrm{v}-16 \mathrm{r}$; note that only two tombs are depicted). In a collective volume with other texts including on magic and divination.

\section{A.3 Indonesia}

Balai Maklumat Kebudayaan Melayu Riau, Penyengat, Riau

- Accession number unknown: Penyengat, mid-nineteenth century. llluminated.

Museum Aceh, Banda Aceh

There are 17 manuscripts of the Daläil in this museum. ${ }^{114}$ These are a few that are known:115

- No. 78 ; No. 296 ; No. 302; No. 313 ; No. 347.

114 Nurdin A.R, "The Manuscript Collection of the Aceh Museum," Indonesia and the Malay World 40 (116) (2012): 94-110: 99.

115 See Museum Aceh, Identifikasi Naskah Koleksi Museum Negeri Aceh. 6 vols. (Banda Aceh: Departemen Pendidikan dan Kebudayaan, Direktorat Jenderal Kebudayaan, Museum Negeri Aceh, 1984-1992). 
Perpustakaan Nasional Republik Indonesia, Jakarta ${ }^{116}$

- A.78: Banten, eighteenth-nineteenth century. Illustration of the rawda (p. 5).

- A.79: Banten, eighteenth-nineteenth century. Illustration of the rawda (p. 3).

- A.8o: Banten, eighteenth-nineteenth century. Illustration of the rawda.

- A.81: Banten, eighteenth-nineteenth century. Illustration of the rawda (p. 3).

- A.168: Sumatra, 1266/1849-1850.

- A.582: Aceh, nineteenth century. Illuminated.

- A.631: Kerinci, nineteenth century. Illuminated.

- W.295: Probably Riau, section on translation of the Qur'an dated 5 Shawwāl 1228/1 October 1813 .

Pesantren Tanoh Abee, Banda Aceh ${ }^{117}$

- No. 105; No. 106.

Surau Haji Muhammad Said Bonjol Collection

- British Library, EAP352/1/6, https://eap.bl.uk/archive-file/EAP352-1-6: West Sumatra, nineteenth century. Two one-page illustrations of the rawda.

Yayasan Pendidikan Ali Hasjmy, Banda Aceh

- 209/ZD/22/YPAH/2005: Aceh, nineteenth century. ${ }^{118}$

\section{A.4 Malaysia}

Islamic Arts Museum Malaysia, Kuala Lumpur

- 1998.1.790: Probably Patani or Kelantan (where it was obtained), nineteenth century. Illuminated; double-page illustration with Mecca and Medina on the right and a collection of objects on the left (fol. 11v-12r).

- 1998.1.1623: Java, 26 Shawwāl 1148/9 March 1736. Illuminated; double-page illustration of the rawda and minbar (fols. $56 \mathrm{v}-57 \mathrm{r}$ ).

- 1998.1.2453: Probably Patani, nineteenth century. Illuminated; double-page illustration with the rawda and minbar on the right and two palm trees with a structure (a mosque?) on the left (fols. $3 \mathrm{v}-4 \mathrm{r}$ ).

116 On these manuscripts, see van Ronkel, Supplement, 173-174; T.E. Behrend, Katalog Naskah Perpustakaan Nasional Republik Indonesia. Vol. 4 (Jakarta: Yayasan Obor Indonesia, Ecole Française d'Extrême-Orient, 1998), 5, 7, 10, 18, 19, 334.

117 See Wamad Abdullah and Tgk. M. Dahlan al-Fairusy, Katalog manuskrip Perpustakaan Pesantren Tanoh Abee Aceh Besar. Buku I (Banda Aceh: Pusat Dokumentasi dan Informasi Aceh, 1980).

118 See Oman Fathurahman and Munawar Holil, Katalog Naskah Ali Hasjmy Aceh. Catalogue of Aceh Manuscripts: Ali Hasjmy Collection (Tokyo: Tokyo University of Foreign Studies, 2007), 250-251. 
- 1998.1.2607: Terengganu, 29 Ramaḍān 1250/29 January 1835. Copied by Syed Muhammad ibn al-Marhum Zainal Abidin al-Idrus. Illuminated; doublepage illustration with Mecca on the right and Medina on the left (pp. 10-11).

Perpustakaan Negara Malaysia, Kuala Lumpur

- FB (A) 1027: Probably Penang, nineteenth century. Donated to the library by Haji Fathil Bashir in $1984 .{ }^{119}$ Illuminated (marginal ornament).

- MSS 1273: Probably Patani, nineteenth century. Illuminated; double-page illustration with the rawda on the right and minbar on the left $(14 \mathrm{v}-15 \mathrm{r})$, immediately followed by a single page illustrating a frond (fol. 15v).

- MSs 1438: Malaysia or Indonesia, nineteenth century. Illuminated; doublepage illustration with the rawda on the right and minbar on the left (fol. 19v2or).

- MSS 1662: Malaysia or Indonesia, 1171/1757. Illuminated.

- MSS 1740 (A): Java, 1188/1774. Double-page illustration with Mecca on the right and Medina on the left (fols. $15 \mathrm{v}-16 \mathrm{r}$ ). In a collective volume with four other texts- two on the Isrā' and Mirāj (in Arabic and Malay, the latter dated 3 Jumādā I 1188/12 July 1774), instructions for performing the hajj and umra (in Malay), and the tale of one of the Prophet's companions, Bilāl ibn Hamāmạ (in Arabic). These are interspersed with magical diagrams.

- MSS 1974: Patani, 15 Ramaḍān 1233/17 July 1818. Copied by Daud bin Fatani. Illuminated; double-page illustration with the rawda on the right and Mecca on the left (fol. 2v-3r).

- MSS 2368: Singapore, Thursday 12 Rajab 1298/9 June 1881. Copied by Haji Muhammad Khafi bin Marhum Haji Sulaiman and Tuan Syed Ahmad bin Almarhum Tuan Syed Muhammad al-Idrus. Illuminated; one-page illustration of the rawda (fol. 19r).

- MSs 2586: Terengganu, Tuesday Șafar 1256/April-May 1840. Copied by Ahmad bin Muhammad bin Husin bin Mustafa bin Sheikh al-Idrus. Illuminated.

- MSS 2996 (E): Probably Sambas, early nineteenth century. Dated Thursday, Shawwāl, but no year given. Contains a note dated 1255/1839-1840 on a business transaction for cloth that was agreed with the Fitur (Dutch official) of Sambas, Borneo, as well as five notes on the births of children. ${ }^{120}$ Illuminated; one-page illustration with the rawda at the top, and a sketch of possibly Mecca at the bottom (fol. 21r). It is possible a preceding illustration

119 Perpustakaan Negara Malaysia, Manuskrip Arab, unpaginated.

120 Many thanks to Annabel Teh Gallop for pointing this out to me. 
is missing because there is a jump in the text on fol. 2ov, which ends abruptly during the description of the rawda. In a collective volume with other texts.

- MSS 3785: Probably Malay peninsula, 3 Rabī' II 1306/7 December 1888. Illuminated; double-page illustration with Mecca on the right and Medina on the left (fols. 9v-1or).

- MSs 3793:Jeruju Besar, 12 Rabī' I 1310/4 October 1892. Owned (and most likely copied by) by Syarif Ibrahim bin Uthman bin Alwi bin Abdul Rahman bin Idrus bin Abdul Rahman al-Idrus. Illuminated; one-page illustration of the rawda (fol. 31v). Also contains notes on births and a death.

- MSS 4356: Aceh, 1258/1842-1843. Illuminated.

- MSS 4625: Aceh, nineteenth century. Illuminated.

- MSS 4780: Aceh, 1181/1767-1768. Copied by Imam Abiz Labba Muhammad Saleh al-Jami. Illuminated; one-page illustration of the rawda (fol. 95v)

\section{A.5 The Netherlands}

Leiden University Library, Leiden ${ }^{121}$

- Or. $175^{1}$ (14): Copied in Natal, Sumatra, dated 29 Shawwāl 1229/14 October 1814. Prayerbook of Imam Bonjol. Illuminated; one-page illustration of Medina on p. 352. There is also a double-page illustration of Mecca and Medina earlier in the manuscript, on pp. 127-128. In a collective volume with other texts.

- Or. 4826: Collected in Aceh in 1877.

- Or. 4976 (4): Aceh, early nineteenth century. Illuminated. In a collective volume with other texts.

- Or. 5720 (8), (9): Banten, eighteenth century.

- Or. 7057a (6): Banten, eighteenth century. Illustration of the rawda.

- Or. 7209 (3): War booty from Aceh, 1896. In a collective volume with other texts.

- Or. 8204 (10): Aceh, nineteenth century. There is an empty frame on f.105r, which might have been intended for an illustration of the rawda. In a collective volume with other texts.

- Or. 8960 (8): Madura, eighteenth century (dated Monday 10Jumādā II). Contains a note on a death in Torjun, Madura, in 177o. In a collective volume with other texts.

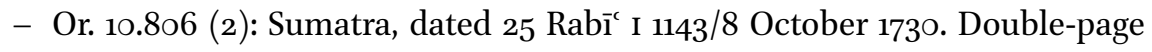
with the rawda on the right and minbar on the left. In a collective volume with other texts.

121 On these manuscripts, see Witkam, Vroomheid; Witkam, "The Battle of the Images." 


\section{Ter Lugt Collection, Leiden}

- MS 31; South Sulawesi, dated 1301/1884, with two empty frames. In a collective volume with other texts, some of which are in the Buginese language, written in Buginese script.

\section{A.6 Singapore}

Asian Civilizations Museum

- 2007-53427: Terengganu, nineteenth century. Illuminated; double-page illustration with Mecca on the right and Medina on the left.

\section{A.7 South Africa}

South African Cultural History Museum, Cape Town

- SACHM 8042: "Ilin" Island (probably Robben Island), Tuesday 22 Ramaḍān $1199 / 29$ July $1785 .{ }^{122}$ Colophon in Malay.

\section{A.8 United Kingdom}

British Library, London ${ }^{123}$

- IO Islamic 2448 (IV). Java, eighteenth/nineteenth century. No illustrations or illumination. In a collective volume with other texts.

- Io Islamic 2618. Java, eighteenth/nineteenth century. No illustrations or illumination.

- IO Islamic 2619 (II). Java, eighteenth/nineteenth century.

- Io Islamic 2939 (I). Java, eighteenth/nineteenth century. No illustrations or illumination. In a collective volume with other texts, with Sufi diagrams and illustrations.

\section{SOAS, University of London}

- MS 45807: Sandıklı, Turkey, dated 1174/176o. Although this manuscript is of Ottoman origin, it contains an interlinear Malay translation in a $d u^{`} \bar{a}$ ' on its flyleaf, hence its inclusion here.

122 Perpustakaan Negara Malaysia, Afrika Selatan (Kuala Lumpur: Perpustakaan Negara Malaysia, 1998), 7, 13 and another unpaginated page.

123 On these manuscripts, see Otto Loth, A Catalogue of the Arabic Manuscripts in the Library of the India Office (London: Printed by order of the Secretary of State for India in Council, 1877), 90, 99, 303 . 


\section{A.9 United States of America}

New York Public Library

- Manuscripts \& Archives, Arabic Ms. No. 256: Probably Wajo, South Sulawesi, 1284/1868. Copied by 'Abd Allah al-Buqisi al-Waj. Illuminated; double-page illustration with Medina on the right and Mecca on the left (fols. 23v-24r).

Private collection of Bruce B. Lawrence ${ }^{124}$

- Probably West Sumatra, first half of the twentieth century. Illuminated.

\section{Bibliography}

Abdul Halim Nasir. Ukiran Kayu Melayu Tradisi. Kuala Lumpur: Dewan Bahasa dan Pustaka, 1986.

Abdul Jalil. "Organisasi Sosial Dala'il Khairat (Studi Pengamal Dala'il Khairat K.H. Ahmad Basyir Kudus)." Inferensi 5, no. 1 (2011): 81-100.

Abdul Malik Ghozali. "The Chains of Transmission of Syeikh Muhammad Mahfudz AtTirmasi in Kifayāt al-mustafid." Heritage of Nusantara 7, no. 1 (2018): 19-45.

Abdul Manan. The Ritual Calendar of South Acèh, Indonesia. Münster, Westfälische Wilhelms-Universität, 2015 .

Abdullah, Wamad, and Tgk. M. Dahlan al-Fairusy. Katalog manuskrip Perpustakaan Pesantren Tanoh Abee Aceh Besar: Buku I. Banda Aceh:Pusat Dokumentasi dan Informasi Aceh, 198o.

Abid, Hiba. "Un concurrent du Coran en Occident musulman du Xe/Xvie à l' aube du Xııe/XVıııe siècle. Les Dalā’il al-khayrāt d'al-Jazūlī." Journal of Qur'anic Studies 19, no. 3 (2017): 45-73.

Abid, Hiba. "Material Images and Mental Ziyāra: Depicting the Prophet's Grave in North African Devotional books (Dalāil al-Khayrat)." Journal of Material Cultures in the Muslim World 1 (2020): 331-354.

Abushouk, Ahmed Ibrahim, and Hassan Ahmed Ibrahim, eds. The Hadhrami Diaspora in Southeast Asia: Identity Maintenance or Assimilation? Leiden: Brill, 2009.

Aladin Hj. Mamat. "Ulama Golongan Syed di Terengganu. Peranan dan Sumbangan dalam Perkembangan Islam." PhD thesis, Universiti Malaya, 2013.

Amiruddin (Abu Teuming). "Melestarikan Budaya Islami Dalail Khairat." Serambinews .com, 25 November 2019, available online at https://aceh.tribunnews.com/2019/11/ 25/melestarikan-budaya-islami-dalail-khairat.

Apria Putra. “Senandung Negeri Seribu Shalawat. Dala’il Khairat di Minangkabau dari

124 See http://www.kevinwfogg.net/blog/4570569437. 
Masa ke Masa." Surau Tuo, 13 November 2014, available online at http://surautuo .blogspot.com/2014/11/senandung-negeri-seribu-shalawat-dalail.html.

Aswandi Syahri. "Kitab Dala’il al-Khayrat, Pegangan Raja Haji Dalam Melawan Belanda." Jantungmelayu, 28 June 2018, available online at https://jantungmelayu.com/ 2018/o6/kitab-dalail-al-khayrat-pegangan-raja-haji-dalam-melawan-belanda/.

Behrend, T.E. Katalog Naskah Perpustakaan Nasional Republik Indonesia. Vol. 4. Jakarta: Yayasan Obor Indonesia, Ecole Française d'Extrême-Orient, 1998.

Ben Cheneb, Mohammed. "Al-Djazūlī." In Encyclopaedia of Islam, New Edition, vol. 2, edited by P. Bearman et al., 527-528. Leiden: Brill, 1965 .

Beyazit, Deniz. "Dala'il al-Khayrat Prayer Book." Aga Khan Museum, https://www.aga khanmuseum.org/collection/artifact/dalail-al-khayrat-prayer-book-akm278

Bruinessen, Martin van. "Kitab Kuning: Books in Arabic Script Used in the Pesantren Milieu: Comments on a New Collection in the KITLv Library." Bijdragen tot de Taal-, Land- en Volkenkunde 146, no. 2/3 (1990): 226-269.

Bruinessen, Martin van. "Mahfuz b. 'Abd Allah Al-Tarmasi (K.H. Mahfudz Tremas, d. 1338/1920)." In Dictionnaire biographique des savants et grandes figures du monde musulman périphérique, du XIXe siècle à nos jours, Fasc. no. 1., edited by Marc Gaborieau et al., 30-31. Paris: CNRS-EHESS, 1992.

Bruinessen, Martin van. "The Origins and Development of the Sufi Orders (Tarekat) in Southeast Asia." Studia Islamika-Indonesian Journal for Islamic Studies 1, no. 1 (1994): 1-23.

Bruinessen, Martin van. "Sufi 'Orders' in Southeast Asia: From Private Devotions to Social Network and Corporate Action." In Buddhist and Islamic Orders in Southern Asia: Comparative Perspectives, edited by R. Michael Feener and Anne M. Blackburn, 125-152. Honolulu: University of Hawaii Press, 2018.

Burak, Guy. "Prayers, Commentaries, and the Edification of the Ottoman Supplicant." In Historicizing Sunni Islam in the Ottoman Empire, c. 1450-c. 1750, edited by Tijana Krstić and Derin Terzioğlu, 232-252. Leiden: Brill, 2020.

Cornell, Vincent J. Realm of the Saint: Power and Authority in Moroccan Sufism. Austin: University of Texas Press, 1998.

Daub, Frederike-Wiebke. Formen und Funktionen des Layouts in arabischen Manuskripten anhand von Abschriften religiöser Texte. Al-Būṣīrīs Burda, al-Ğazūlīs Dalä̀il und die Šifā’ von Qā

Direktorat Jenderal Pendidikan Islam Kementrian Agama RI. Ensiklopedi Islam Nusantara. Edisi Budaya. Jakarta, Direktorat Jenderal Pendidikan Islam Kementrian Agama RI, 2018.

Drewes, G.W.J. Een ı6de eeuwse Maleise vertaling van de Burda van al-Būșīrī. 's-Gravenhage: Martinus Nijhoff, 1955 .

Ebied, Rifaat Y., and M.J.L. Young. "A List of the Appellations of the Prophet Muhammad." The Muslim World 66, no. 4 (1976): 259-262. 
Ediwar, Mohamed Anwar Omar Din, and Zulayti Zakaria. "Kesenian Bernuansa Islam Suku Melayu Minangkabau." Jurnal Melayu 5 (2010): 227-249.

Ellis, Alexander G. "Translation of the Introduction Prefixed to the Dalâ'il al-khayrât in the Edition Lithographed in Cairo in A.H. 1281 (A.D. 1864)." In Guide to Happiness: A Manual of Prayer, by Abū 'Abdullāh Muhammad ibn Sulaymān al-Jazūlī. translated by John B. Pearson, 73-76. Oxford: Printed for private circulation, 1907.

Evans, Ivor H.N. "Some Malay Patterns and Designs." Journal of the Federated Malay States Museum 12 (1924-1929), 163-167, figs. i-x.

Fathurahman, Oman, and Munawar Holil. Katalog Naskah Ali Hasjmy Aceh. Catalogue of Aceh Manuscripts: Ali Hasjmy Collection. Tokyo: Tokyo University of Foreign Studies, 2007.

Farish A. Noor, Eddin Khoo and David Lok. Spirit of Wood: the Art of Malay Woodcarving: Works by Master Carvers from Kelantan, Terengganu and Patani. Singapore: Periplus, 2003.

Farouk Yahya. "A Dalā'il Al-Khayrāt Manuscript in the Perpustakaan Negara Malaysia (MSS 1273)." MA thesis, soAs University of London, 2006.

Farouk Yahya. Magic and Divination in Malay Illustrated Manuscripts. Leiden: Brill, 2016.

Farouk Yahya. "Introduction." In "Malay manuscripts: A Guide to Paper and Watermarks. The collected works of Russell Jones 1972-2015," ed. Farouk Yahya. Special issue, Indonesia and the Malay World 49 (144) (2021): 139--394.

Freitag, Ulrike. Indian Ocean Migrants and State Formation in Hadhramaut: Reforming the Homeland. Leiden: Brill, 2003.

Gacek, Adam. Catalogue of the Arabic Manuscripts in the Library of the School of Oriental and African Studies, University of London. London: School of Oriental and African Studies, 1981.

Gallop, Annabel Teh. "Seni Hias Manuskrip Melayu." In Warisan Manuskrip Melayu, 239-259. Kuala Lumpur: Perpustakaan Negara Malaysia, 2002.

Gallop, Annabel Teh. "An Acehnese Style of Manuscript Illumination.” Archipel 68 (2004): 193-240.

Gallop, Annabel Teh. "The Spirit of Langkasuka? Illuminated Manuscripts from the East Coast of the Malay Peninsula." Indonesia and the Malay World 33 (2005): 113-182.

Gallop, Annabel Teh. "Islamic Manuscript Art of Southeast Asia." In Crescent Moon: Islamic Art \& Civilisation in Southeast Asia, edited by James Bennett, 158-189. Adelaide: Art Gallery of South Australia, 2005.

Gallop, Annabel Teh. "Palace and Pondok: Patronage and Production of Illuminated Manuscripts on the East Coast of the Malay Peninsula." In Warisan Seni Ukir Kayu Melayu / Legacy of the Art of Malay Woodcarving, edited by Zawiyah Baba, 143162. Bangi: Institut Alam dan Tamadun Melayu, University Kebangsaan Malaysia, 2010. 
Gallop, Annabel Teh. "Islamic Manuscript Art of the Philippines." In The Qur'an and Islamic Manuscripts of Mindanao, edited by Kawashima Midori, 71-105 + figures. Tokyo: Institute of Asian Cultures, Sophia University, 2012.

Gallop, Annabel Teh. "Qur’an Manuscripts from Mindanao: Collecting Histories, Art and Materiality." South East Asia Research 2021 DoI: 10.108o/og67828X.2021.1895674.

Gallop, Annabel Teh, and Ali Akbar. "The Art of the Qur'an in Banten: Calligraphy and Illumination." Archipel 72 (2006): 95-156.

Gazali. "Wisata Ziarah. Potensi Ekonomi Umat di Lokasi Makam Syekh Moehammad Yoesoef Tilatang Kamang Kabupaten Agam." Suluah 14, no. 18 (2014): 43-48.

George, Alain. "Calligraphy, Colour and Light in the Blue Qur'an." Journal of Qur'anic Studies 11, no. 1, (2009): 75-125.

Göloğlu, Sabiha. "Depicting the Islamic Holy Sites: Mecca, Medina, and Jerusalem in Late Ottoman Illustrated Prayer Books," in 15th International Congress of Turkish Art, edited by Michele Bernardini and Alessandro Taddei, with the collaboration of Michael Douglas Sheridan. Ankara: Ministry of Culture and Tourism, 2018.

Graves, Margaret S. "Double-Page Composition Showing Mecca and Medina." In Architecture in Islamic Arts: Treasures of the Aga Khan Museum, edited by Margaret S. Graves and Benoît Junod, 44-45, cat. 2. Geneva: Aga Khan Trust for Culture, 2011. Hamka. Sejarah Islam di Sumatra. Medan: Pustaka Nasional, 1950.

Haldi Patra. "Kelompok Shalawat yang Membaca Dalailul Khairat di Kecamatan Padang Tangah Payobadar Kota Payakumbuh." no date [c. 2017].

Hickman, Bill. "Note on a Nineteenth-Century Painting of the Sacred Precinct in Mecca." In "Other Places: Ottomans Traveling, Seeing, Writing, Drawing the World," edited by Gottfried Hagen and Baki Tezcan, special double issue of Journal of Ottoman Studies / Osmanlı Araştırmaları 39 (2012): 17-28.

Ho, Engseng. The Graves of Tarim: Genealogy and Mobility Across the Indian Ocean. Berkeley, CA: University of California Press, 2006.

Ibrahim Alfian. "Dimensi Agama dan Reaksi Dunia Melayu Terhadap Penetrasi Barat di Abad XVIII dan XIX Khasnya di Riau, Melaka, Palembang, dan Aceh." Humaniora 1 (1989): 71-86.

Izrin Muaz Md Adnan. "A History of the Acheen Street Malay Enclave from Oral History Accounts." Journal of the Malaysian Branch of the Royal Asiatic Society 85, no. 1 (2012): 1-44.

al-Jazūlī, Abū 'Abdullāh Muḥammad ibn Sulaymān. Guide to Happiness: A Manual of Prayer, translated by John B. Pearson. Oxford: Printed for private circulation, 1907. al-Jazūlī, Abū 'Abdullāh Muhammad ibn Sulaymān. Petunjuk Cara Memperoleh Syafaat Nabi sAw: Terjemah Dalailul Khairat, translated by Abdul Ghoni Asykur. Bandung: Husaini, 1997.

Johns, Anthony H. "Islamization in Southeast Asia: Reflections and Reconsiderations 
with Special Reference to the Role of Sufism." Southeast Asian Studies 31, no. 1 (1993): $43^{-61 .}$

Kartomi, Margaret. "The Development of the Acehnese Sitting Song-Dances and Frame-Drum Genres as Part of Religious Conversion and Continuing Piety." Bijdragen tot de Taal-, Land- en Volkenkunde 166, no. 1 (2010): 83-106.

Katz, Marion. The Birth of the Prophet Muhammad: Devotional Piety in Sunni Islam. Abingdon: Routledge, 2007.

Kawashima, Midori, ed. A Provisional Catalogue of Southeast Asian Kitabs of Sophia University (Second Version). Tokyo: Institute of Asian Cultures-Center for Islamic Area Studies, Sophia University, 2015.

Loth, Otto. A Catalogue of the Arabic Manuscripts in the Library of the India Office. London: Printed by order of the Secretary of State for India in Council, 1877.

M. Bagus Irawan. "Sanad Dalail Khairat di Nusantara." Iqra.id, 2 April 2020, available online at https://iqra.id/sanad-dalail-khairat-di-nusantara-219751/.

Mabrur. "Pudarnya Eksistensi Dalail Khairat di Negeri Syariat." Serambinews.com, 9 December 2018, available online at https://aceh.tribunnews.com/2018/12/o9/pudarnya -eksistensi-dalail-khairat-di-negeri-syariat.

Melati Ismaila Rafici and Saifuddin Zuhri Qudsy. "Transmisi, Sanad Keilmuan dan Resepsi Hadis Puasa Dalāil Al-Khairāt." Mutawatir 1o, no. 1, (2020), 1-26.

Mohammad Redzuan Othman. "The Arabs Migration and Its Importance in the Historical Development of the Late Nineteenth and Early Twentieth Century Malaya." Paper presented at the 15th Annual World History Association Conference, Long Beach, California, 22-25 June 2006.

Mohd. Zahamri Nizar. "Dari Patani ke Riau-Lingga. Kajian Iluminasi Manuskrip Dalailal-Khayrat Pulau Penyengat." In Prosiding Persidangan Antarabangsa Manuskrip Melayu 2017, 17-35. Kuala Lumpur: Perpustakaan Negara Malaysia, 2017.

Muhammad Abdul Kharis. "Puasa Dalail al-Qur’an dalam Perspektif Hadis (Studi Kasus di Pondok Pesantren Putra Darul Falah Jekulo Kudus)." Undergraduate dissertation. Universitas Islam Negeri Walisongo, Semarang, 2017.

Muhammad, Mualimbunsu Syam. Motivasi Perang Sabil di Nusantara. Kajian Kitab Ramalan Joyoboyo, Dalailul-Khairat, dan Hikayat Perang Sabil. Jakarta: Media Madania, 2013.

Museum Aceh. Identifikasi Naskah Koleksi Museum Negeri Aceh. 6 vols. Banda Aceh: Departemen Pendidikan dan Kebudayaan, Direktorat Jenderal Kebudayaan, Museum Negeri Aceh, 1984-1992.

National Heritage Board. "Guide to Goodness (Dalail al-Khayrat)." Roots, https://www .roots.sg/learn/collections/listing/1031226.

Nurdin A.R. "The Manuscript Collection of the Aceh Museum." Indonesia and the Malay World 40 (116) (2012): 94-110.

Ohta, Alison. "Front Binding and Case." In Objects of Instruction: Treasures of the School 
of Oriental and African Studies, edited by Anna Contadini. London: School of Oriental and African Studies, 2007, reprinted 2016, 108, cat. 85 .

O'Meara, Simon. The Ka'ba Orientations: Readings in Islam's Ancient House. Edinburgh: Edinburgh University Press, 2020.

O'Neill, Hugh. "South-East Asia." In The Mosque: History, Architectural Development \& Regional Diversity, edited by Martin Frishman and Hasan-Uddin Khan, 224-240. Cairo: American University in Cairo Press, 2002.

Perpustakaan Negara Malaysia. Manuskrip Melayu Koleksi Perpustakaan Negara Malaysia. Satu Katalog Ringkas. Tambahan Ketiga. Kuala Lumpur: Perpustakaan Negara Malaysia, 1997 .

Perpustakaan Negara Malaysia. Katalog Manuskrip Melayu di Afrika Selatan. Kuala Lumpur: Perpustakaan Negara Malaysia, 1998.

Perpustakaan Negara Malaysia, Katalog Manuskrip Melayu. Koleksi Perpustakaan Negara Malaysia. Kuala Lumpur: Perpustakaan Negara Malaysia, 2000.

Perpustakaan Negara Malaysia, Katalog Manuskrip Melayu. Koleksi Perpustakaan Negara Malaysia. Tambahan Pertama. Kuala Lumpur: Perpustakaan Negara Malaysia, 2001.

Perpustakaan Negara Malaysia, Katalog Manuskrip Melayu. Koleksi Perpustakaan Negara Malaysia. Tambahan Kelima. Kuala Lumpur: Perpustakaan Negara Malaysia, 2008.

Perpustakaan Negara Malaysia, Katalog Manuskrip Melayu. Koleksi Perpustakaan Negara Malaysia. Tambahan Kesepuluh. Kuala Lumpur: Perpustakaan Negara Malaysia, 2018.

Perpustakaan Negara Malaysia. Manuskrip Arab Koleksi Pusat Manuskrip Melayu. Kuala Lumpur: Perpustakaan Negara Malaysia, [no date].

Porter, Venetia. The Art of Hajj. London: British Museum Press, 2012.

Proudfoot, Ian. "Malay Books Printed in Bombay: A Report on Sources for Historical Bibliography." Kekal Abadi 13, no. 3 (1994): 1-20.

Raja Haji Ahmad and Raja Ali Haji. Tuhfat al-Nafis, edited by Virginia Matheson. Kuala Lumpur: Fajar Bakti, 1982.

Ricklefs, Merle C., Petrus Voorhoeve and Annabel Teh Gallop. Indonesian Manuscripts in Great Britain: A Catalogue of Manuscripts in Indonesian Languages in British Public Collections. New Edition with Addenda et Corrigenda, Jakarta: Yayasan Pustaka Obor Indonesia, 2014.

Ronkel, Ph.S. van. Supplement to the Catalogue of the Arabic Manuscripts Preserved in the Museum of the Batavia Society of Arts and Sciences. Batavia: Albrecht \& Co.; The Hague: M. Nijhoff, 1913 .

Roxburgh, David J. "Visualizing the Sites and Monuments of Islamic Pilgrimage." In Architecture in Islamic Arts: Treasures of the Aga Khan Museum, edited by Margaret S. Graves and Benoît Junod, 33-40. Geneva: Aga Khan Trust for Culture, 2011. 
Rusli, Nurul Iman, et al. Dala'il al-Khayrat: Prayer Manuscripts from the 16th-19th Centuries. Kuala Lumpur: Islamic Arts Museum Malaysia, 2016.

Schmitz, Barbara. Islamic Manuscripts in the New York Public Library. New York: Oxford University Press, 1992.

Syed Hadzrullathfi Syed Omar, et al. "Works by Terengganu's Scholars of the 19th Century in Dignifying the Study of Islamic Knowledge Based on the al-Quran." Asian Social Science 10 (2014): 128-136.

al-Tarmusī, Muḥammad Maḥūz bin 'Abdillah. Kifāyat al-mustafìd li-mā 'alā min alasānìd. Beirut: Dār al-Bashāìr al-Islāmiyya, 1987 .

Wan Mohd. Shaghir Abdullah. "Syeikh Mahfuz At-Tarmasi. Ulama Hadis Dunia Melayu." Utusan Malaysia, 13 June 2005. Republished online at http://ulama.blog spot.com/2005/o6/syeikh-mahfuz-at-tarmasi.html.

Wiesmüller, Beate. "Von Istanbul nach Palembang. Die unerschlossenen islamischen Handschriften der Universitätsbibliothek." In Das Buch in Antike, Mittelalter und Neuzeit. Sonderbestände der Universitätsbibliothek Leipzig, edited by Thomas Fuchs, Christoph Mackert and Reinhold Scholl, 281-303. Wiesbaden: Harrassowitz, 2012.

Witkam, Jan Just. Vroomheid en Activisme in een Islamitisch Gebedenboek. Leiden: Legatum Warnerium, Universiteitsbibliotheek Leiden, 2002.

Witkam, Jan Just. Inventory of the Oriental Manuscripts of the Library of the University of Leiden, 25 vols. Leiden: Ter Lugt Press, 2002-2019.

Witkam, Jan Just. "The Battle of the Images: Mekka vs. Medina in the Iconography of the Manuscripts of al-Jazūlī's Dalā'il al-Khayrat." In Theoretical Approaches to the Transmission and Edition of Oriental Manuscripts, edited by Judith Pfeiffer and Manfred Kropp, 67-82 (text), 295-299 (illustrations). Beirut: Ergon Verlag Würzburg, 2007.

Witkam, Jan Just. "The Islamic Pilgrimage in the Manuscript Literatures of Southeast Asia." In The Hajj: Collected Essays, edited by Venetia Porter and Liana Saif, 214-223. London: British Museum, 2013. 